
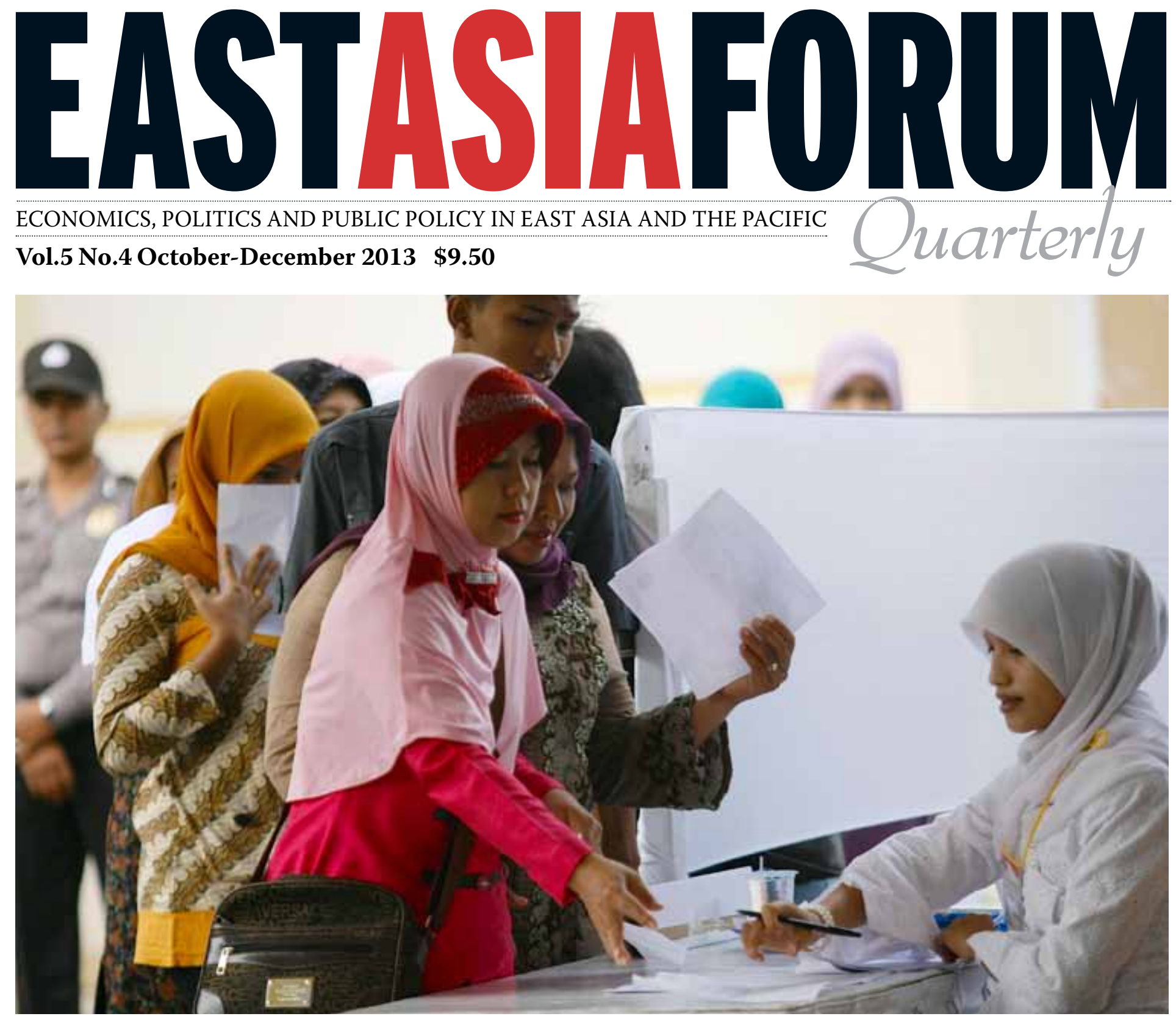

\title{
Indonesia's choices
}

Mahendra Siregar and others Seizing the infrastructure opportunity

Hugh White Old-world assumptions in Australian relations

Dewi Fortuna Anwar Reinvention in Indonesia's foreign policy strategy

Djisman Simandjuntak Towards 'escape velocity'

Edward Aspinall Change of pace ahead after the SBY stasis 


\section{EASTASIAFORUM \\ Quarterly \\ ISSN 1837-5081 (print) \\ ISSN 1837-509X (online)}

\section{From the editors' desk}

What next for Indonesia? By any measure, the past 15 years has been a period of extraordinary progress. Yet for all the impressive gains, there is a widespread sense-especially inside Indonesia-that the early pace of progress has fallen away; even that the country is now just marking time and waiting for whatever the 2014 electoral cycle might yield.

The essays in this $E A F Q$ reflect the unease about the chances of being able to keep on the right track.

Indonesia is an unambiguous economic success story. Sustained growth has lifted living standards, lowered the incidence of poverty, and underpinned social stability and political reform. But there is mounting concern that Indonesia is becoming mired in sticky 'middle income mud'.

The country now faces increasingly acute bottlenecks in key areas of economic infrastructure. The grand plans for upgrading infrastructure trumpeted over the past decade have not been realised. Maritime transportation-vital for an archipelagic nation-is woefully underdeveloped. Inadequate capacity for generating electricity is emerging as a major constraint in many areas. And the education system is falling further behind in the fundamental task of producing an adequately skilled workforce.

Indonesia's next president and next parliament will need to address these problems squarely, or economic momentum will ebb away. The good news is that they will do so from within the context of a relatively established democratic system of government. The bad news is that Indonesia's system of government is unwieldy, with authority and responsibility blurred between the executive and legislature, and between the national and local levels of government. Whatever the policy agenda, whoever the leaders, this is a difficult system to operate.

Internationally, Indonesia has emerged as an active and effective player on the regional and even global diplomatic stages. Although it is likely the next president will be, either by temperament or necessity, more domestically oriented, Indonesia will remain pivotal to regional affairs. Other countries-and none more so than Australia-need to recalibrate their mindsets about Indonesia. Even if Jakarta's new-found pride and confidence periodically exceed its capacities, other countries-and, again, none more so than Australia-will find the costs of underestimating Indonesia increasingly painful.

\section{Andrew MacIntyre and Maria Monica Wihardja}

www. eastasiaforum.org
CONTENTS

\section{ARIANTO PATUNRU}

Building a more equitable and productive Indonesia

\section{MARCUS MIETZNER}

A strong base for democratic development

\section{EDWARD ASPINALL}

A change of pace ahead after the SBY stasis

\section{DEWI FORTUNA ANWAR}

Reinvention in Indonesia's foreign policy strategy

12 MAHENDRA SIREGAR, ANDREW ELEK AND MARIA MONICA WIHARDJA

Seizing the infrastructure opportunity

\section{DIONISIUS NARJOKO}

Why Indonesia needs to drive integration

16 SJAMSU RAHARDJA

Time to regain confidence

18 YOSE RIZAL DAMURI

What's wrong with the TPP

\section{BLANE D. LEWIS}

Public services: the legacy of decentralisation

\section{HERFAN BRILIANTO}

Mobilising private investors

\section{RAYMOND ATJE}

Energy options

\section{DANIEL SURYADARMA}

Can Indonesia educate itself out of middle-income status?

\section{FITRIAN ARDIANSYAH}

Climate change: protecting forests for the future

\section{NOOR HUDA ISMAIL}

Rehabilitating terrorists: management, not ostracism

\section{HARTADI A. SARWONO}

Capital flows: managing the benefits and risks

33 DJISMAN SIMANDJUNTAK

Towards 'escape velocity'

\section{HUGH WHITE}

Old-world assumptions will cruel

dealings with Australia 


\section{Building a more equitable and productive Indonesia}

\section{ARIANTO PATUNRU}

\section{A}

T THE beginning of 2013

Indonesia's economy looked to be in good shape. Growth was still over 6 per cent; inflation was manageable at below 5 per cent. Then on 22 May 2013 came a signal from the US Federal Reserve that it would begin to scale back its quantitative-easing program. In Indonesia, in an attempt to reduce budgetary burdens, the government reduced the fuel subsidy and so increased the fuel price on 22 June. These two events, combined with increases in the minimum wage and food prices, as well as the continued slowdown in many advanced countries, have contributed to a rather different picture of the Indonesian economy in the second half of 2013.

The net inflows of portfolio investment that were so strong in the first quarter have now started to slow-in some cases they have even reversed-in response to US stimulus taper talk. The rupiah has come under pressure. And the inflationary effect of food and fuel price changes has started to kick in. Capital formation has also slowed down. By September 2013 Indonesia's growth rate had gone down to 5.6 per cent, inflation exceeded 8 per cent, and the rupiah had fallen by more than 15 per cent against the US dollar.

Of course the country has seen worse. The situation following the 1997-98 Asian financial crisis was much bleaker. Yet, slowly, the country managed to recover and the economy

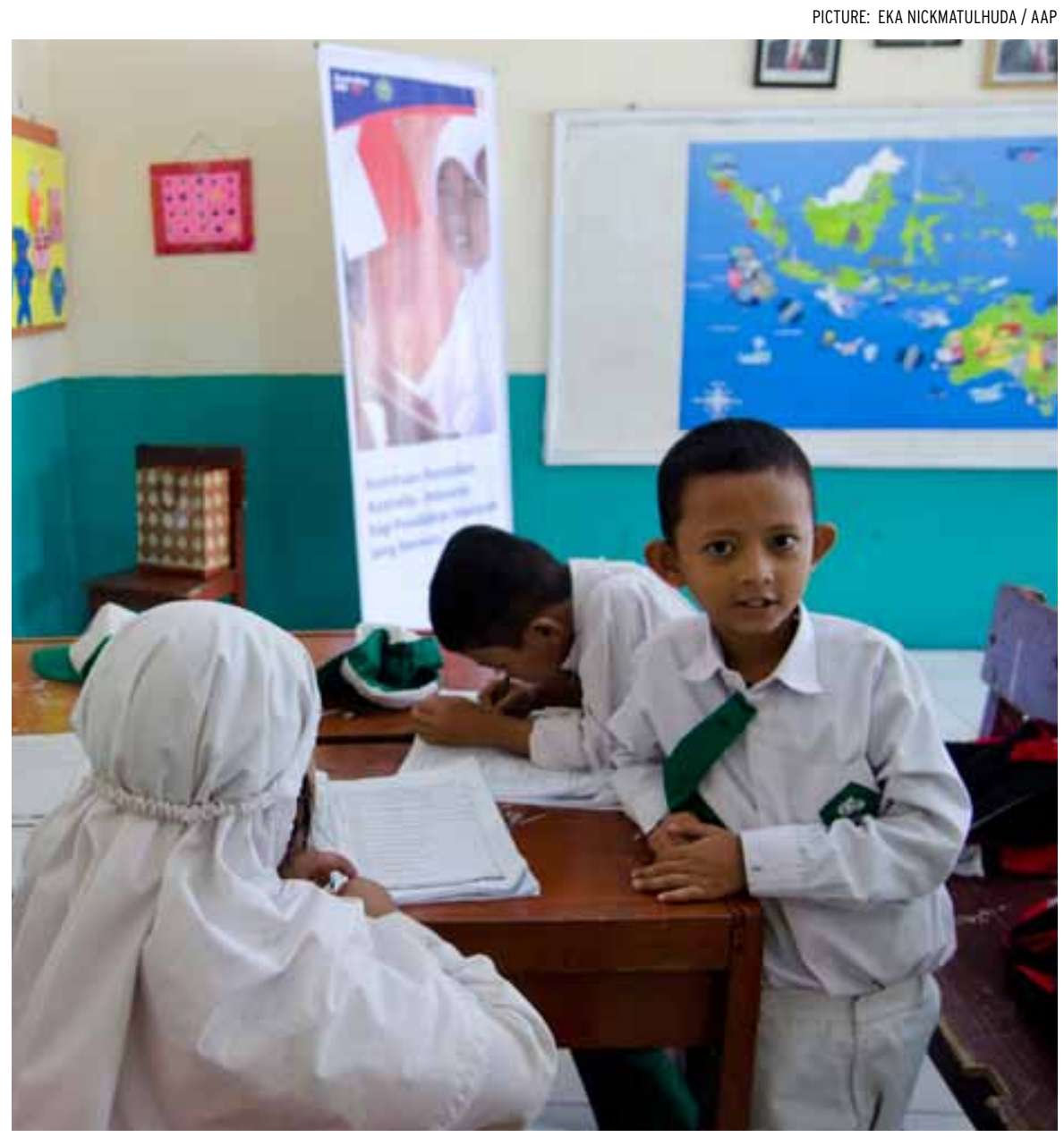

Children at their studies at Madrasah Manarul Huda Islamic school in Jakarta in April 2013. Improving equality of access to education is one of the key elements in assuring Indonesia's future prosperity.

was surprisingly resilient amid the 2008-09 global financial crisis. The recent episode in 2013 is but a small hiccup if seen through the longer-run trajectory of Indonesian economic dynamics. It is therefore important not to lose sight of long-term structural reforms. In this regard, two issues are of particular relevance to Indonesia: productivity and inequality.

With a total GDP of US $\$ 878$ billion,
Indonesia is among the 20 richest countries in the world. In per capita terms, however, this translates to around US $\$ 5,000$ at purchasing power parity, which places Indonesia above India and the Philippines but well below China, Thailand and Malaysia. Indonesia's relatively small output per capita can be partially explained by technological productivity. Indonesia's total factor productivity, relative to 
EASTASIAFORUM

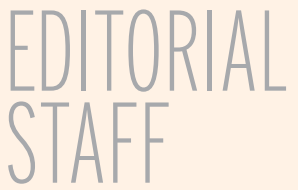

Issue Editors

Andrew MacIntyre, Dean of the ANU

College of Asia and the Pacific.

Maria Monica Wihardja, economist and consultant, the World Bank.

\section{Editors}

Peter Drysdale, Head, East Asia Forum and East Asian Bureau of Economic Research, Crawford School, ANU.

Shiro Armstrong, Executive Director, East Asia Forum and East Asian Bureau of Economic Research, Crawford School, ANU.

\section{Editorial Staff}

Mark Fabian, Kai Ito, Madeleine Willis, ANU.

Editorial Advisers: Peter Fuller, Max Suich.

Production: Peter Fuller, Words \& Pics. Original design: Peter Schofield.

Email Peter.Drysdale@anu.edu.au, Shiro.Armstrong@anu.edu.au.

The views expressed are those of the individual authors and do not represent the views of the Crawford School, ANU, EABER, EAF, or the institutions to which the authors are attached.

COVER PHOTO: A woman casts her vote in the Banda Aceh local election in April 2012. Picture: HOTLI SIMANJUNTAK / EPA / AAP.

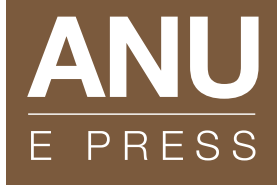

Published by ANU E Press The Australian National University Canberra ACT 0200, Australia Email: anuepress@anu.edu.au Web: http://epress.anu.edu.au
US levels, dropped significantly after the Asian financial crisis. It has yet to recover, despite a period of quite stable growth. Currently, Indonesia's productivity level is below most other countries in the region.

Furthermore, the wage employment elasticity of growth has gone down from 0.56 in 1991-2001 to 0.45 in 2001-11. This indicates that a higher rate of output growth is needed for every percentage of employment growth. But the change in wage employment elasticity may also imply one or both of the following: that technological progress has been more labour-saving or, given that the measure mostly captures the formal sector, that the informal sector has grown bigger. In fact, the number of unpaid and own-account workers (those in 'vulnerable employment') in Indonesia's labour force has reached 60 per cent, compared with, for example, 40 per cent in the Philippines.

The second area in need of attention is inequality. Indonesia's economic growth and poverty-reduction programs have been impressive. But increasing income inequality could constrain the effectiveness of growth in reducing poverty. Indonesia fares better than China, the Philippines and Thailand - and is far above Malaysiain its Gini ratio (or in other measures of inequality, such as the ratio of income shares held by the highest 10 per cent compared to the lowest 10 per cent). Nevertheless, Indonesia's inequality has deteriorated from 0.33 in 2007 to 0.41 today, with urban areas showing higher inequality $(0.43)$ than rural areas (0.33).

But inequality is not just about income differences. What matters more for future prosperity is access to education and healthcare. In 2010, the literacy rate in Indonesia was 95 per cent for males and 90 per cent for females. In the meantime, 18 per cent of Indonesians still used rivers, lakes, unprotected springs or unprotected dug wells as their main sources of drinking water. Worse yet, 46 per cent of the population could only access unimproved sanitation (sanitation facilities that do not ensure the hygienic separation of human excreta from human contact) - and 36 per cent of the population in rural areas practiced open defecation.

These conditions vary across regions in Indonesia, but the case of one of the least developed provinces, East Nusa Tenggara, as compared with Jakarta, is illustrative. Income per capita in Jakarta was close to US\$9,875 in 2010, while in East Nusa Tenggara it was only US\$650-a 15-fold difference. Close to 9 per cent of the population aged 10 or above in East Nusa Tenggara did not go to school, and 9 per cent of households had undernourished babies. The numbers in Jakarta, on the other hand, were 1.7 and 3 per cent, respectively.

Improving equality in access to basic education and healthcare is therefore key. There are many ways to

An enabling environment

that connects the

outcomes from better

education and health

\section{conditions to increased}

productivity is

necessary 


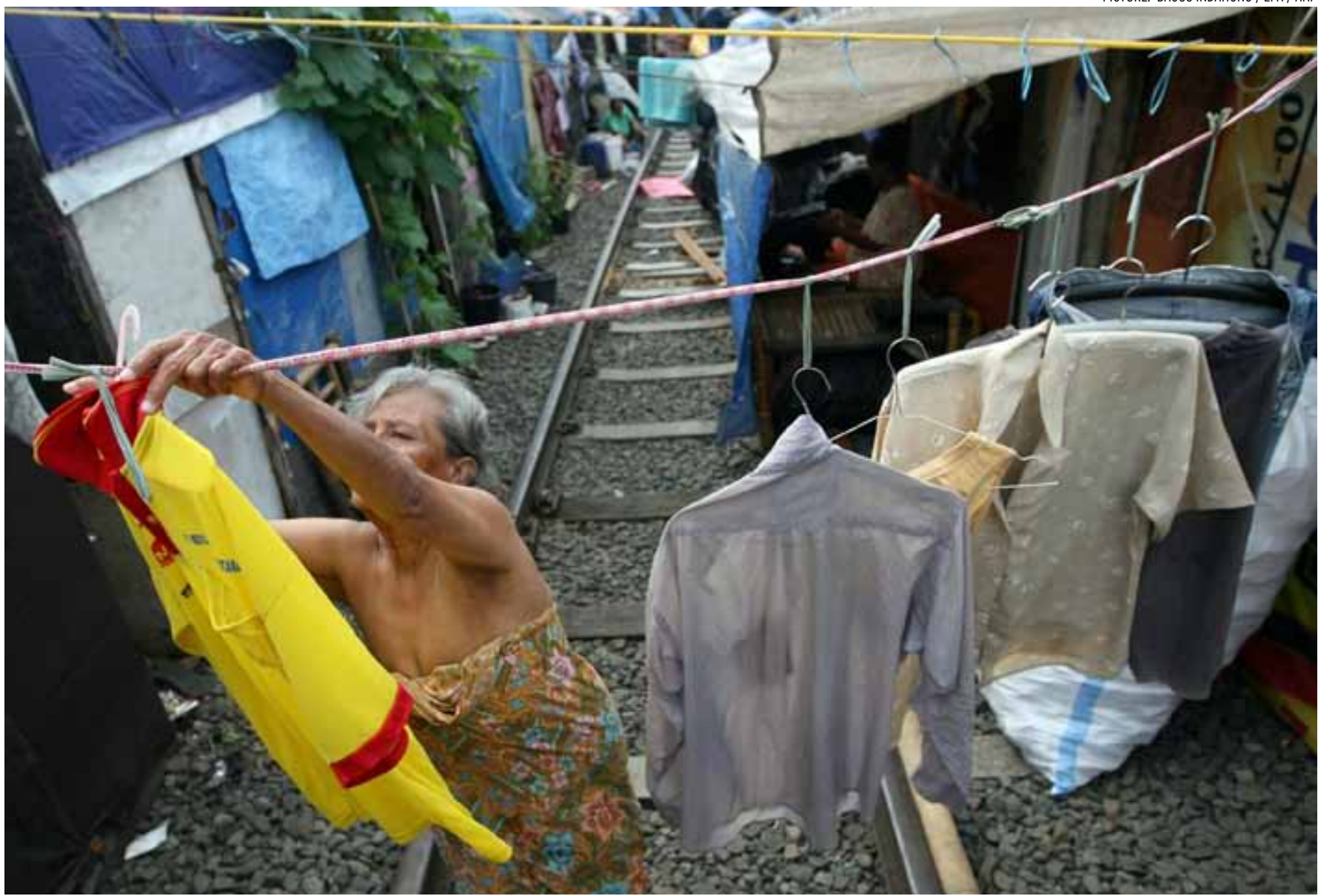

A woman dries her washing in a poor area in Jakarta. In 2010, 18 per cent of people used rivers, lakes or unprotected wells and springs for drinking water.

do this, but one of the most important prerequisites is budgetary support.

Only 5 per cent of government expenditure goes towards health, while 15 per cent goes to education. This is in stark contrast with Thailand, for example, which spends 14 per cent of government expenditure on health and 30 per cent on education. Perhaps not surprisingly, both malnourishment and illiteracy rates are higher in Indonesia than in Thailand.

The recent fuel subsidy adjustment in Indonesia is commendable. But it is not enough. In fact, in the proposed 2014 budget, the fuel subsidy still crowds out education and health spending: the amount allocated to these two sectors is around 66 per cent and 6 per cent, respectively, of that allocated to the fuel subsidy. Getting the funding right, along with other issues such as curriculum improvements and access to universal healthcare, is critical to reaping the benefits of the so-called demographic dividend-which will start to subside in around 10 years' time.

Finally, an enabling environment that connects the outcomes from better education and health conditions to increased productivity is necessary. This includes a more flexible labour market and a strong social protection system. In an economy that is undergoing structural change, higher labour mobility would be beneficial. The role of manufacturing is now gradually decreasing, while the importance of the services sector is increasing. In 2012 services value added represented 40 per cent of GDP, which was still among the region's lowest levels. While employment in services has reached 44 per cent of total employment, the sector is still primarily made up of informal workers and small- and medium-sized enterprises. A more flexible market would help the transition from low- to high-productivity services and would go some way in securing Indonesia's future prosperity. EAFQ

\section{Dr Arianto Patunru is a fellow at the Arndt-Corden Department of Economics and policy engagement coordinator at the Indonesia Project, Crawford School of Public Policy, Australian National University.}




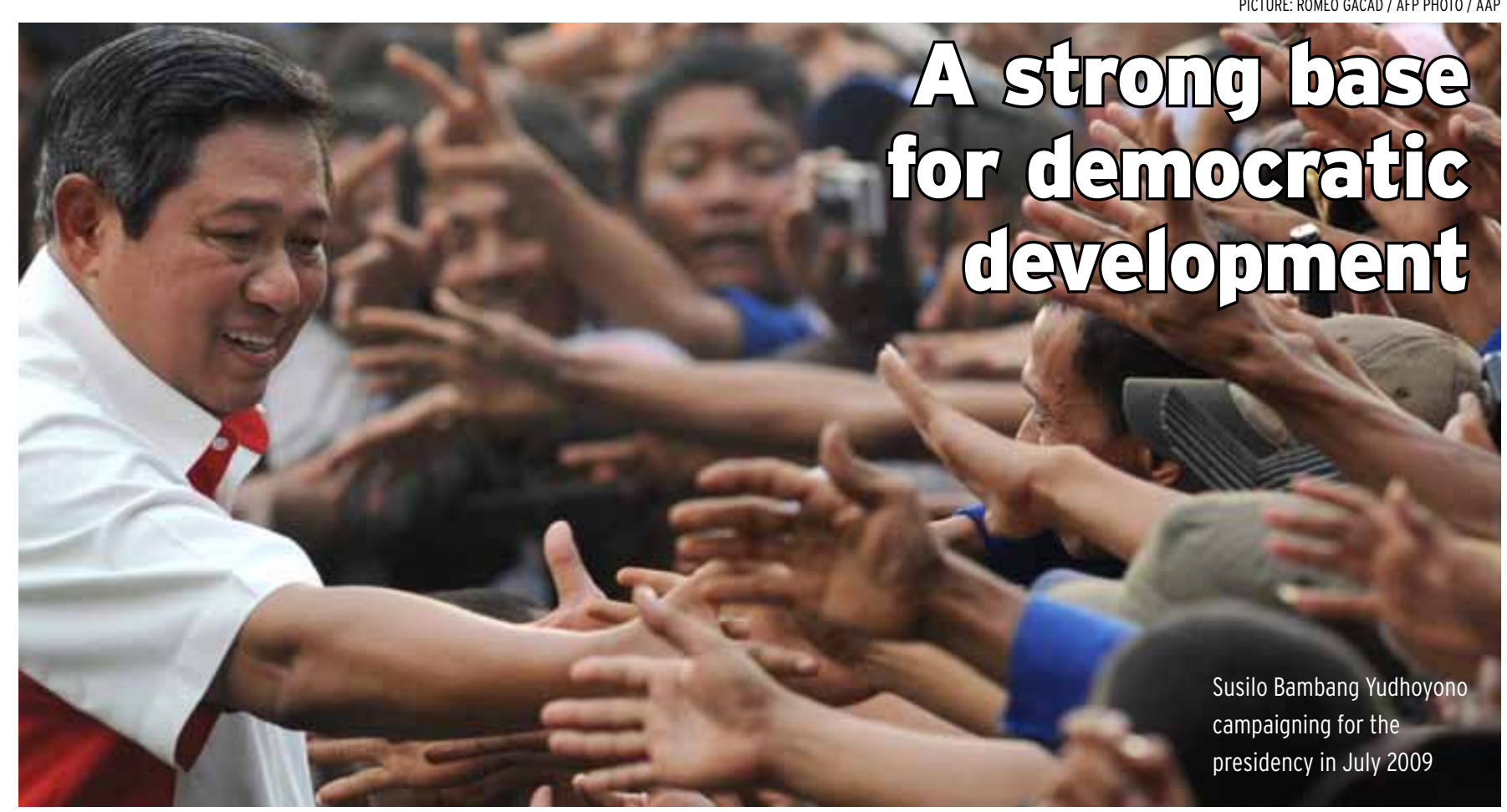

MARCUS MIETZNER

N MAY 2013, Indonesia

celebrated the 15th anniversary of the downfall of President Suharto's authoritarian New Order regime. Yet while Suharto and his rule are more and more relegated to the history books, there is still no agreement among observers and ordinary citizens about the character of the state that emerged after 1998. Some view the post-Suharto state as a model Muslim democracy that has proved to be much more resilient than any of its Arab Spring counterparts. Others believe that Suharto's associates simply hijacked Indonesia's new democratic institutions and thus survived the transition unharmed. Others still are convinced that the state is controlled by both old and new oligarchic forces, making democracy a sham.

So what is the state of Indonesian democracy 15 years after the end of authoritarianism? Unsurprisingly, the report card is mixed. The democratic transition has been marked by both significant successes and dramatic failures-as one would expect from a state trying to overcome deeply entrenched legacies of military hegemony, political and societal corruption, communal tensions, and low levels of economic development. But overall, the bottom line is that Indonesia today has a functioning electoral democracy. According to Freedom House, it has been Southeast Asia's freest society since 2006. This is a remarkable achievement given the chaos surrounding Suharto's departure in 1998. To begin with, Indonesia avoided territorial disintegration in a period in which the Soviet Union, Yugoslavia and Czechoslovakia (to name only a few) decided to dissolve their unitary states. To a large extent this was due to the unprecedented program of decentralisation launched in 1999 which silenced secessionist calls in Bali, East Kalimantan and Riau. In combination, democratisation and decentralisation allowed Indonesia's regions to express their local identities and formulate their own policy priorities-something that had been impossible under the centralist regimes that had governed Indonesia since 1945.

Similarly, Indonesia has successfully marginalised the military in political affairs-in contrast to Egypt, for example, where the army aborted the democratic experiment after only two tumultuous years. The story of Indonesia's democratisation after 1998 is primarily a narrative of comprehensive civilianisation, both in the centre and in the regions. At the end of Suharto's rule, 40 per cent of Indonesia's governors were retired or active military; by 2013 , a mere 6 per cent. It is difficult to overstate the significance of this development, especially given widespread predictions in 1998 that another coup was only a matter of time.

Equally remarkable is the ease with which Indonesia institutionalised electoral procedures that are widely 
viewed as free, fair and competitive. There have been three national elections since 1999, two of which led to peaceful changes in government, and almost one thousand ballots at the provincial and district level since 2005. While administrative problems, votebuying, and corruption in electoral dispute resolution persist, elections are now generally accepted as the only game in town. In a country that did not witness a free election for an entire generation (the last democratic poll before Suharto's fall was in the late 1950s), such a seamless transition from autocracy to electoral democracy could not be taken for granted.

Finally, post-Suharto democracy also destroyed the long-held myth that only authoritarian rulers can guarantee sustained economic growth. Indeed, it was Suharto who was responsible for the country's economic collapse in 1998, after which the democratic polity cleaned up the mess. Growth has averaged between 5 and 6 per cent throughout the 2000s, and the debt-to-GDP ratio now stands at 25 per cent-a figure many Western democracies would envy.

All these successes notwithstanding, there is frustration among the Indonesian populace about a slowdown in the reform process since the mid-2000s. Under the government of Susilo Bambang Yudhoyono (who came to power in 2004 and whose second term will end in October 2014), democratic gains were consolidated but no further ground-breaking reforms were launched. In fact, many democracy activists have noted that Yudhoyono presided over an erosion of democratic quality in a number of key policy areas.

Most importantly, the level of political corruption in Indonesia has increased in recent years. While the country's Anti-Corruption
Commission has carried out a number of high-profile arrests (ranging from ministers to the Chief Justice of the Constitutional Court), the incentives for corruption still outweigh the risks of being caught. Crucially, Yudhoyono's decision in 2005 to cut state subsidies to political parties by 90 per cent has led the latter to intensify their predatory fundraising practicesparty cadres in public office have increasingly siphoned off money from national and local budgets in order to fund the parties' operational expenses. Of course, the corrupted money is also used to fund exceedingly lavish lifestyles among the political elite.

A T THE same time, some conservative circles in the Home Ministry and other political agencies have tried to roll back electoral reforms introduced since the early 2000s. The Home Ministry submitted a proposal to parliament in 2013 that, if passed into law, would lead to the abolition of direct elections for mayors and district heads (who, not coincidentally, hold great political and fiscal powers under Indonesia's decentralisation regime). The move reflected anxiety among some political leaders about the extent to which Indonesians have been democratically empowered since 1998, and it also signalled that there are elite groups determined to recapture the privileges they enjoyed before the vast expansion of electoral rights.

There is also a noticeable deterioration in the protection of religious minority rights in postSuharto Indonesia. Attacks on Christian churches and Islamic non-mainstream groups such as the Ahmadis and the Shiites have increased dramatically under Yudhoyono's government, with the president unable or unwilling to confront the radical militias responsible for the violence. When Yudhoyono received an award in New York in May 2013 that honoured him for efforts in promoting religious freedom in Indonesia, the president was showered with ridicule and sarcasm by both concerned citizens at home and democracy advocates abroad.

Yet on balance, Indonesian democracy is more stable, more advanced and more deeply rooted in society than most observers would have expected in 1998. It is obviously far from fully consolidated, and equally far from becoming a liberal democracy in which the rule of law, civil liberties and minority rights are upheld without prejudice. But given the almost complete absence of democratic experience at the beginning of the transition, Indonesia's stability as a functional electoral democracy 15 years later is a noteworthy achievement, and one that many young democracies in the Middle East and elsewhere would like to replicate.

For Indonesia, the next challenge is to organise an orderly transfer of power from Yudhoyono to his democratically elected successor. The alternatives couldn't be clearer: the front-runner so far-hugely popular Jakarta governor Jokowi Widodostands for a reinvigoration of the reform process. His most serious rival, Suharto's former son-in-law Prabowo Subianto, calls for tougher leadership and a nationalist revival. Ultimately, the choices Indonesians make in this contest will reveal a lot about the kind of democracy the country has become since shaking off authoritarianism. EAFO

Dr Marcus Mietzner is Senior Lecturer in the ANU College of Asia and the Pacific. 


\section{A change of pace ahead after the SBY stasis}

\section{EDWARD ASPINALL}

USILO Bambang Yudhoyono's presidency will come to an end in 2014. Lauded internationally as a reformer and moderniser, at home SBY (as he is popularly known) is largely viewed as a disappointment. Heavy on rhetoric and obsessed with his personal dignity, he has been reluctant to offend powerful economic actors or the parties that make up his governing coalition. As a result, it is difficult to identify any major reform agenda that Yudhoyono set out to achieve at the outset of his presidency in 2004 and successfully pursued to completion in the years that followed.

Despite this record, his tenure will probably largely be viewed positively as a period of stabilisation after the years of economic crisis and turbulent political transition that preceded it. Riding high on a commodity boom, GDP growth has averaged just under 6 per cent during his time in office. Moreover, though SBY initiated no major political reforms, he was also not destructive of past achievements. Most importantly, he did not buckle to pressure from other members of the political elite to cripple Indonesia's Corruption Eradication Commission even as it claimed a series of scalps of high-profile politicians and bureaucrats in sting investigations and prosecutions.

Yet if Indonesia is to become the successful and dynamic society its leaders dream of, SBY's successorwhoever he or she will be-will need

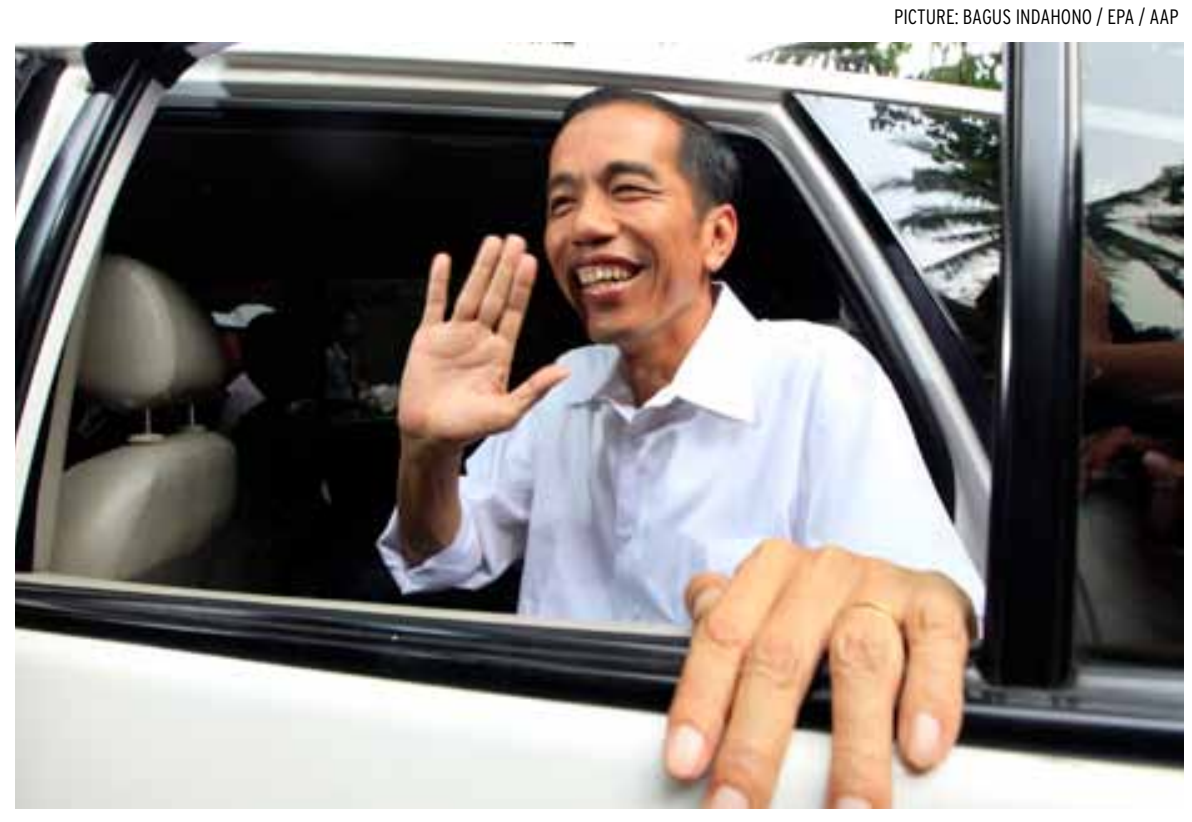

Jokowi 'Joko' Widodo during his campaign for Jakarta governor in September 2012. Strongly favoured as a candidate for the presidency, he has a record in reforming healthcare and government processes.

to attend to several pressing reforms that proceeded only haltingly during the SBY years. In fact, one could say that drift needs to be arrested and urgent action taken in almost any area of public policy, but there are three, below, that are especially pressing.

Healthcare and welfare reform is a major priority. One of the least remarked-upon but also most profound transformations of the SBY years is that issues of social welfareeducation, pensions and, especially, healthcare-moved to the centre of political debate. To a large extent provincial and district governments have been driving this trend, with image-savvy politicians introducing local health insurance schemes to appeal to voters in local elections. But in 2011 Indonesia's national parliament also passed a new law establishing the framework for a national social security system that will, among many other things, provide universal health insurance for Indonesian citizens. The Economist describes this new system as "building the biggest "single-payer" national health scheme-where one government outfit collects the contributions and foots the bills-in the world'. In a country with notoriously bad-quality public health services, and public health spending that is low even by Southeast Asian standards, this is an enormous challenge, but one that promises to spread some of the benefits of Indonesia's middle-income status to its legions of poor.

Formally, the new system will begin to come into effect in 2014, but 
huge administrative, financial and other challenges remain. A basic task is to ensure that reality matches the rhetoric: Indonesia's public health centres and hospitals often lack the facilities, medicines and staff they are officially assigned. In the longer term, if the country really wants to provide high-quality healthcare to all its citizens, the national government will need to devote much greater expenditure to the sector, something that only a few policymakers are starting to wake up to. Indonesians, especially wealthier ones, may find they need to pay higher taxes. Collecting more taxes will in turn require reform-not least, cleaning out the corrupt taxation bureaucracyand put pressure on the government to perform much better in service delivery.

Anticorruption and public service reform is also essential. Almost every reform issue in Indonesia comes back to corruption. For several years, as a result of the Corruption Eradication Commission's sting investigations, Indonesians have been alternately scandalised and titillated by the stream of dramatic exposés of corrupt activity at the very top. One of the latest involved the arrest of the chief judge of the country's highest court, accused not only of receiving enormous bribes but also of possessing crystal methamphetamine. Patronage is the lubricant of the entire political system, but many of the problems can be traced back to the civil service and the arcane regulations that govern it. The problems have been well-known for years: complex and non-transparent remuneration systems, a rigid system of promotions and barriers to hiring people from outside the system, to name just a couple. Yet reforming the system has been likened by Professor Sofian Effendi, one of Indonesia's chief advocates of bureaucratic reform, to an Indonesian version of Waiting for Godot.

After many years of drafts and preparation, the national parliament seems to be ready to pass a reform bill into law. It looks likely to bring significant change, though the record of the legislature indicates there are risks that the law could be riddled with inconsistencies and imprecision. Whatever happens, a new president will need to bring this issue back into focus: several experiments at reform began during SBY's tenure, but petered out.

Finally, infrastructure development is necessary. In recent years Indonesia has been swept by a wave of workers' strikes in its industrial zones. Employers have complained that the resulting wage rises are making Indonesia less attractive as an investment destination. But what rarely makes it into the media is that it's primarily Indonesia's poor infrastructure that is making the country uncompetitive. Transporting goods to ports and shipping them out of the country is far more costly-and far more subject to delay-than in comparable Asian nations. Fixing infrastructure was meant to be a major priority of SBY's government right from the start, and big international conferences were held to kick-start investment. While progress has been made in some areas, such as electricity

... it's primarily

Indonesia's poor

infrastructure that is

making the country

uncompetitive generation, anyone who has braved Jakarta's traffic, or sat through hours of electricity blackouts in any number of towns, knows this is still a crippling problem.

Months of political manoeuvring lie ahead before it becomes clear who exactly the candidates in next July's presidential election will be. At this stage there are two favourites. The strongest candidate is Jokowi Widodo, Jakarta's governor and the former mayor of Solo in Central Java. Interestingly, he cut his political teeth on two of the reform issues mentioned above: he introduced a popular healthcare card scheme in Solo and subsequently brought it to Jakarta, and streamlined government processes and made efforts to improve public services.

Prabowo Subianto, the secondstrongest candidate, is a very different man. A former general-and former son-in-law of President Suharto-he is from the heart of Indonesia's oligarchic elite, but someone who has rebranded himself as a fiery economic nationalist and champion of the poor. He has little to say about technical matters of reform but instead postures as a strong man who will sweep aside whatever obstacles are stopping Indonesia from working better.

Gentle reform or a crash-through approach: whatever happens, at this stage it looks unlikely that Indonesia will be in for more of the long stasis of the SBY years.

Edward Aspinall is a professor of politics at the School of International, Political and Strategic Studies, ANU College of Asia and the Pacific. He is the author of Opposing Suharto: Compromise, Resistance and Regime Change in Indonesia (2005) and Islam and Nation: Separatist Rebellion in Aceh, Indonesia (2009). 


\section{Reinvention in Indonesia's foreign policy strategy}

\section{DEWI FORTUNA ANWAR}

17 E HAVEN'T heard much

about Indonesia's 'concentric circles' foreign policy lately, a concept that gained currency when Mochtar Kusumaatmadja served as Indonesian foreign minister from 1978 to 1988 and continued to be popular until the end of the New Order.

The idea was that instead of pursuing a globalist foreign policy as President Sukarno had done when he tried to position Indonesia as a leading light among the 'new emerging forces' confronting colonialism and imperialism, President Suharto would pursue more modest foreign policy goals centred on Indonesia's needs for security, stability and economic development.

Indonesia's foreign policy priorities would be based on geographic proximity, with the inner circle encompassing ASEAN (seen as the cornerstone of Indonesian foreign policy), the second circle comprising major neighbouring countries in East Asia, the third circle the wider Asia Pacific region, with the outer perimeters being of diminishing importance. Thus the Asia Pacific was the focus of Indonesia's foreign policy interests and strategic priorities throughout most of Suharto's New Order period, while relations with countries and regions beyond were selective, on the basis of what they could offer Indonesia economically.

Since then new buzz words have emerged in Indonesia's foreign policy practice, though the adherence to the 'free and active' foreign policy doctrine, introduced in 1948 as a means for Indonesia to strike an independent path in the face of the bipolar rivalry, has been reiterated from time to time.

Under the brief presidency of Abdurrahman Wahid (Gus Dur), between 1999 and 2001, then-foreign minister Alwi Shihab, a professor of comparative religions, stated that Indonesia would follow an 'ecumenical' foreign policy with a strong trend towards globalism. This was reinforced by Gus Dur's penchant for overseas travel-in the spirit of ecumenism he made a point of visiting countries at odds with each other, such as Cuba immediately after visiting the United States. After Gus Dur left office the concept of ecumenical foreign policy also went out of fashion.

In recent years President Susilo Bambang Yudhoyono has asserted that Indonesia's foreign policy is based on 'thousands of friends [later a million] and zero enemies'. And foreign minister Marty Natalegawa has popularised the so-called doctrine of 'dynamic equilibrium'. Unlike in a more traditional adversarial 'balance of power' concept, a 'dynamic equilibrium' seeks to involve all the major relevant powers within a more cooperative framework as a basis for developing an inclusive regional architecture.

In truth, despite the seemingly major changes in priorities and styles, there are also basic elements of continuity that mark Indonesia's foreign policy, besides the emphatic adherence to the 'free and active' principle. Indonesian foreign policy under SBY has combined key elements from the earlier years, and nowhere are these more discernible than in the Asia-Pacific region.

From the Sukarno era Indonesia inherits a strong sense of idealism and a missionary outlook that seeks to manage if not transform its strategic environment, projecting self-confidence even when lacking the means to carry out its policies effectively.

a VIDENTLY, the emphasis in Indonesian regional policy has moved away from the confrontational character of the Sukarno years and has been replaced by close cooperation with neighbouring countries to the extent of forming a regional community.

Still, the desire to promote norms and values that would allow Indonesia and other similarly situated countries in the region the autonomy to be their own masters, instead of merely followers of more powerful states, has remained strong. By itself and through ASEAN as the cornerstone of its foreign policy, Indonesia has consistently tried to carve a bigger role in designing and shaping the regional order, at least within the inner concentric circles.

Despite the current strong emphasis on good neighbourly relations and economic pragmatism (a legacy of 


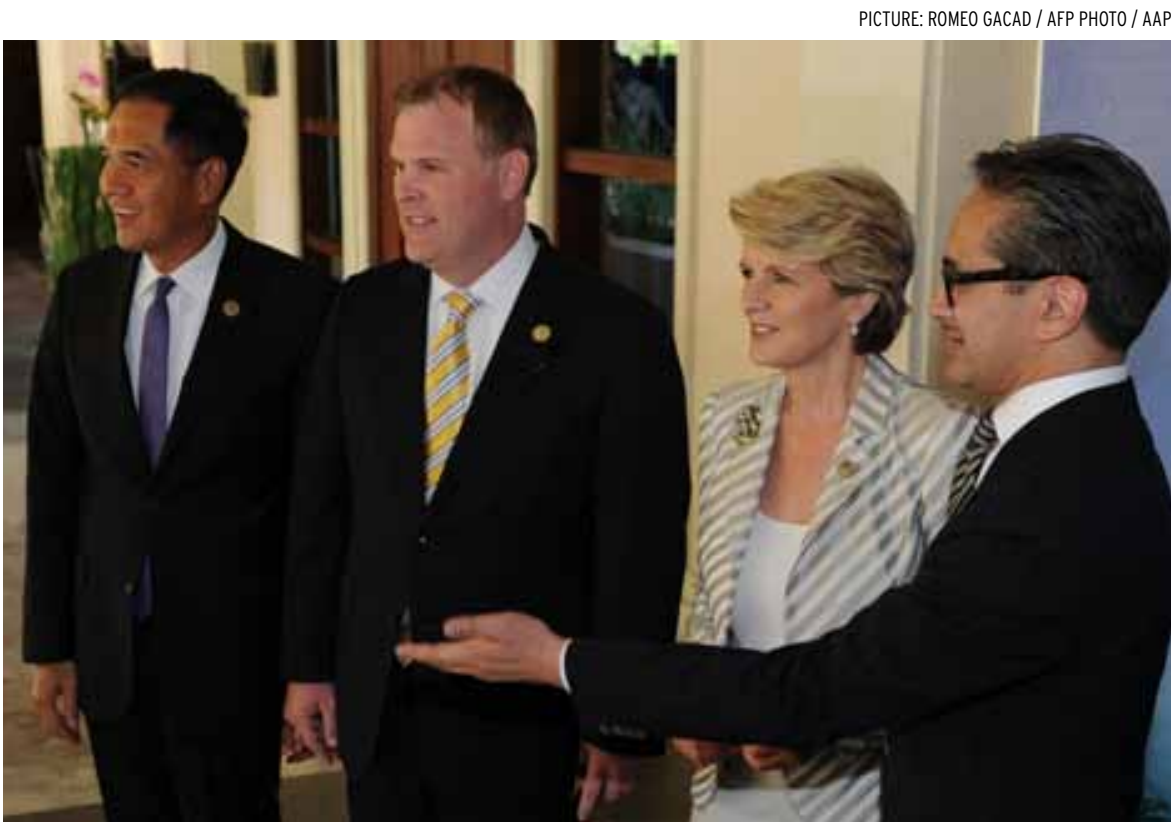

Canadian and Australian foreign ministers John Baird and Julie Bishop, centre, with Indonesian Trade Minister Gita Wirjawan, left, and Foreign Minister Marty Natalegawa at the APEC ministerial summit in Bali in October 2013. Jakarta has become more active on the global stage.

the New Order, discussed below), the strong nationalism and jingoism of the Sukarno period still flares up occasionally. Nationalistic passion is naturally aroused when a foreign country is seen to be slighting Indonesia's national pride-something that happens with rather regular frequency with Indonesia's closest neighbours and regional partners, Australia and Malaysia. Nevertheless, while calls for 'konfrontasi' can still be heard when bilateral tensions flare up-as with recent revelations that Australian spies tapped the phones of President Yudhoyono, the first lady and several other cabinet members in 2009-pragmatism has mostly acted as a brake.

A strong dose of pragmatism, utilitarianism and desire for a safe neighbourhood in Indonesian foreign policy-compelled by expectations that foreign policy initiatives bring concrete benefits to the wider public beyond international prestigeremains a legacy of Suharto's New

\section{Order period.}

The dominant themes of the New Order's foreign policy have undoubtedly continued to colour Indonesia's regional and international outreach, though new themes have also emerged, such as the promotion of Indonesia's soft power assets as the world's third-largest democracy and the largest majority Muslim nation.

\section{A}

LTHOUGH it is no longer explicitly stated, Indonesia has in fact continued its concentric circles foreign policy approach with much national time and energy devoted to the realisation of the ASEAN Community by 2015 . Beyond ASEAN, priority has been given to relations within the ASEAN+3 (China, Japan and South Korea), the East Asia Summit and APEC. Within these circles it is important to note that, as in the earlier period, concerns for security based on relationships with immediate neighbours predominates; for countries in the outer circles,
Indonesia's emphasis is more on securing and safeguarding economic interests. Also demonstrating where Indonesia's foreign policy priorities lie is the fact that almost all of the strategic and comprehensive partnerships that Indonesia has entered into are with Asia-Pacific countries, though in the past few years Jakarta has also become more active on the global stage.

With the end of the Cold War and the onset of a more pluralistic democracy in Indonesia, it is important to acknowledge that the brief Gus Dur interregnum has also left an indelible mark of 'ecumenical' foreign policy as Jakarta now sets out to befriend everyone (at least normatively) and play the role of a 'unifier.' This stands in contrast to the ideologically driven aspects of Sukarno's and Suharto's foreign policies (the former vehemently anticolonialism and -imperialism-read the West-and the latter virulently anti-communist).

In the current multipolar world order Indonesia can exercise its 'free and active' foreign policy with much greater flexiblity than during the Cold War-though risks of great power conflicts still exist, particularly in the Asia Pacific where US and Chinese interests contend. Espousing the concept of a dynamic equilibriumand inviting all the relevant great powers into the East Asia Summit, where no one power dominatesJakarta is indeed trying to be a champion of foreign policy ecumenism in the region. EAFQ

\section{Dewi Fortuna Anwar is Deputy} Secretary for Political Affairs to the Vice President of the Republic of Indonesia and Research Professor at the Indonesian Institute of Sciences (LIPI). 


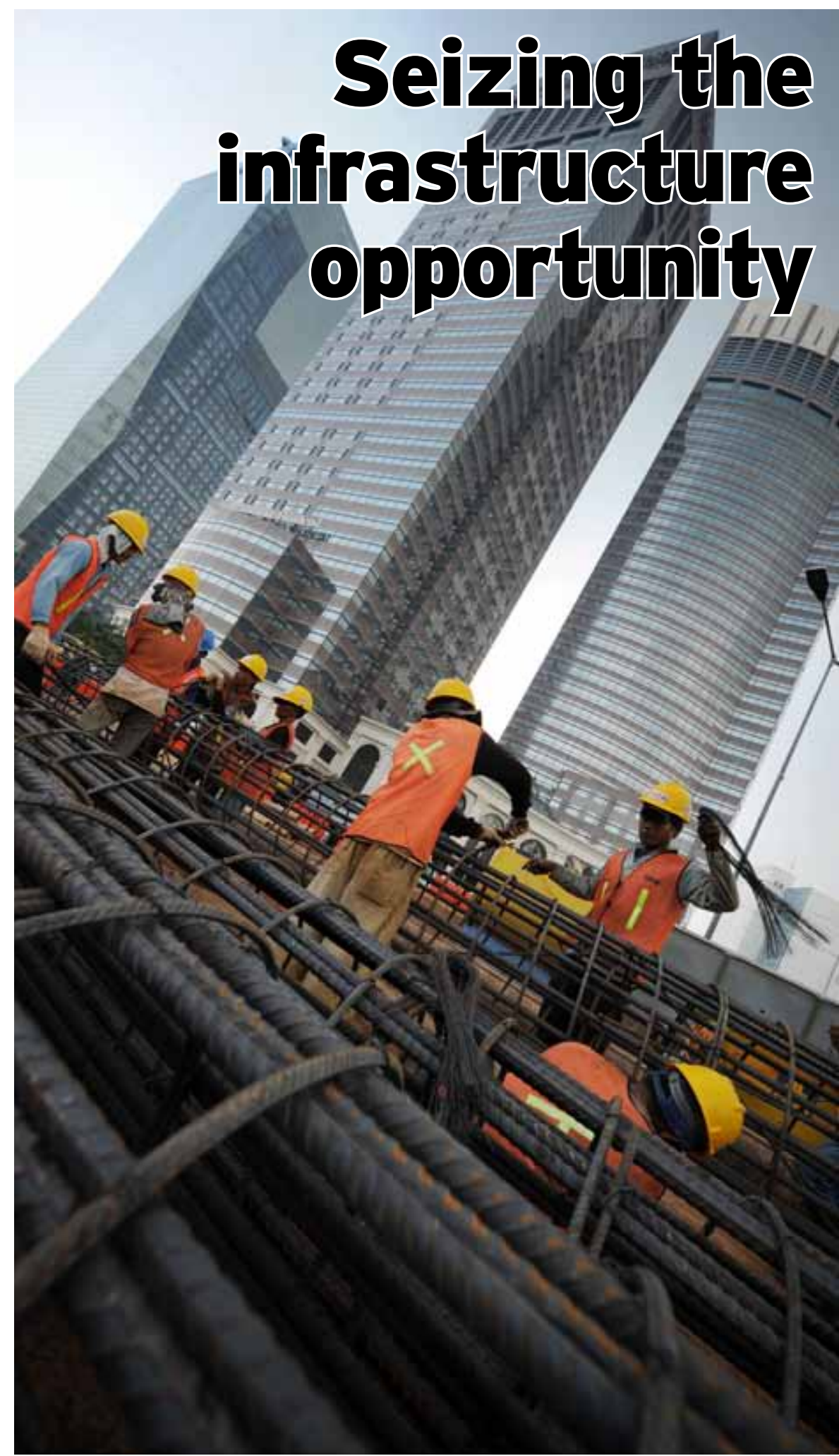

Workmen bed down the reinforcing for an elevated roadway in Jakarta. In recent years Indonesia has begun to build institutions that will help the nation's infrastructure development.

PICTURE: ROMEO GACAD / AFP PHOTO / AAP
MAHENDRA SIREGAR, ANDREW ELEK AND MARIA MONICA WIHARDJA

5 IVE years after the 2008 global financial crisis, the world economy is still operating well below capacity, largely because of serious policy mistakes in 'advanced' economies. Extraordinarily loose monetary policy has not been enough to counter the perverse fiscal austerity forced on the Eurozone by Germany and on the United States by the Tea Party. This combination of macroeconomic policy settings is not only inefficient-it is also unsustainable. The resulting uncertainty is delaying new investment despite very low interest rates, which in turn is causing high unemployment and long-term social costs. The potential GDP of the United States is already 7 per cent below its pre-crisis trajectory.

A significant boost to effective demand is needed to revive the global economy's momentum. To be big enough, any new stimulus needs to be coordinated-no economy can do enough alone. And to be affordable, the stimulus needs to raise productivity. The G20 can coordinate a multilateral initiative to accelerate investment, steering more of the world's savings to finance some of the vast unmet demand for productive economic infrastructure.

The OECD estimates the demand for infrastructure with sound potential economic returns to be US\$50 trillion for the next two decades. The Asian Development Bank estimates that emerging economies in Asia should invest US $\$ 8$ trillion by 2020 to sustain their growth. Global savings are accumulating at a rate that is more than enough to meet this demand. Most governments have some fiscal policy space to invest in bankable 
economic infrastructure projects and they can use it to stimulate a gradually larger flow of private investment.

Boosting investment in productive infrastructure can inject urgently needed effective demand into the global economy, raise confidence in recovery and add to long-term potential for growth. In a world of international production networks and low border barriers to most of the products that move along these supply chains, coordinated funding for transport and communications infrastructure is also the most efficient way to reduce the costs of international commerce among economies.

$\mathbf{T}$ HIS is why Indonesia is determined to seize the global infrastructure opportunity through G20 leadership.

In 2011, Indonesia proposed that infrastructure investment be the new focus for the G20's Framework for Strong, Sustainable and Balanced Growth. The goal is to reduce global imbalances and lift growth by redirecting excess savings, especially in Asia, to finance infrastructure investment in both developing and advanced economies instead of flowing as portfolio investments to advanced economies to finance debts. It also proposed a framework to develop a pipeline of projects which focused on the assessment of country-level capacities to deliver and implement bankable projects. Lastly, Indonesia proposed that the G20 explore innovative ways to channel global savings into productive economic infrastructure, to find new sources of financing and new mechanisms to diversify investment risks.

In recent years Indonesia has progressed in building institutions to help infrastructure development.
These include presidential regulations to strengthen government guarantee and finance for infrastructure as structural reform priorities and the creation of the Indonesia Infrastructure Guarantee Fund, Viability Gap Fund, Land Fund, and Indonesia Infrastructure Guarantee Fund Institute, although some of these are still not yet completed or fully operating.

Australia has made infrastructure development the top priority for its year as the G20 host, but it remains to be seen whether international cooperation can go beyond enthusiastic statements about the global infrastructure opportunity and potentially endless studies. It will never be possible to remove all constraints on all investments in all places: in reality, all infrastructure projects will come up against unexpected problems. If investment in economic infrastructure is to accelerate significantly, some governments will need to show how problems implementing some important initiatives can be overcome. Then others can learn from these examples.

ASEAN governments are playing their part through investments to create the ASEAN Economic Community. In October 2013 APEC leaders committed themselves to creating a comprehensively connected Asia Pacific region that will lead to significant investments in the software and hardware needed to enhance physical, institutional and people-topeople connectivity. Under Indonesia's APEC chairmanship, a Public-Private Partnership (PPP) Centre (under Indonesia's Ministry of Finance) was established as a pilot project for centres throughout the region, to be overseen by an APEC PPP Expert Advisory Panel.
China's recent initiative to establish the Asian Infrastructure Investment Bank (AIIB) is a potential game-changer. Indonesia has welcomed this initiative and stated its intention to participate in the new development bank. The AIIB can be expected to accelerate investment in economic infrastructure to boost Asia's productivity. Not simply by offering a new potential source of money (financing is not the binding constraint on improving economic infrastructure) but by being decisive and clear about what is needed to get projects off the ground. There are many good opportunities for economically viable investment to improve connections among Asian economies. These include coordinating an Asia Pacific effort to upgrade the efficiency of major ports and airports to bring their performance closer to best practice, and taking advantage of Myanmar's recent decision to engage with the international economy to build high-capacity transport and communications links between East Asia and South Asia.

If ASEAN and APEC governments work with the new AIIB, they can seize these opportunities, drawing in substantial private investment along the way.

$\mathbf{E}$ XISTING development banks can, and should, do much more to steer savings towards infrastructure. At present, the commercial arms of multilateral development banks are net borrowers from developing economies, so it is not surprising that China has decided to create a new bank. All multilateral development banks now have a new strong incentive to look for ways to expand their capital base and expertise. They can also speed up their efforts and update their practices to leverage investment from 


\section{ASEAN}

institutional investors, and others, by co-financing and/or underwriting projects in innovative ways.

If Indonesia, and perhaps Asia Pacific and some other G20 governments, make early decisions to be stakeholders in the new AIIB, the stage will be set for cooperation between, as well as healthy competition among, all development banks. This could help to rekindle global economic recovery by filling some of the yawning gaps in global economic infrastructure.

Indonesia must lead by example. It will benefit from these regional and global initiatives if it puts its own house in order, including improving domestic connectivity. Regional and global initiatives on infrastructure investment must be supported by a domestic reform agenda that makes them central to national priorities. EAFQ

Mahendra Siregar is Chairman of Indonesia's Investment Coordinating Board and was formerly Indonesia's G20 Sherpa.

Andrew Elek is a Research Associate at the Crawford School of Public Policy, Australian National University. He was the inaugural Chair of APEC Senior Officials in 1989.

Maria Monica Wihardja is an economist, consultant at the World Bank.

The views in this article are the authors, and do not necessarily reflect those of their institutions.

This article is based on the authors' forthcoming book chapter, 'G20 and Regional Organisations', in Peter Drysdale and Kemal Dervis, eds. G20 at Five, to be published by Brookings Institution Press in 2014.

\section{Why Indonesia needs to drive integration}

DIONISIUS NARJOKO

A $S$ THE biggest country in Southeast Asia, Indonesia is a natural leader of ASEAN. For decades since the association was established in 1967, Indonesia has played an important role maintaining geopolitical stability in the region. This leadership has recently become more demanding due to border disputes within ASEAN and China's territorial claims in the South China Sea.

Indonesia also assumes leadership on ASEAN economic matters, albeit, some would argue, not sufficiently actively. Still, at the Bali Summit in 2003, Indonesia was bold enough to introduce the establishment of an ASEAN Economic Community (AEC) by 2020 (later accelerated to 2015) as the central ASEAN objective and, more recently, during the Bali Summit in 2011, putting in place the Regional Comprehensive Economic Partnership (RCEP) by 2015.

But progress toward establishing the AEC has been modest. While there have been some notable achievements, critical targets for laying a robust

\section{Analysis. insight. On line. Twice dally.}

eastasiaforum.org foundation of a fully integrated and equitable ASEAN are yet to be achieved. With 2015 now just the year after next, time is running out, and the need to address the challenges and obstacles to realising the AEC was acknowlegded by ASEAN leaders at their 2012 Phnom Penh meeting.

The RCEP is a new regional trade agreement built upon the ASEANcentered free-trade agreements (FTAs) involving, all six ASEAN dialogue partners (Japan, China, South Korea, Australia, New Zealand and India). Because of its structure, RCEP is perceived as a new trade bloc that consolidates all of ASEAN's 'plus-one' FTAs, with the objective of creating a broader and deeper engagement with significant improvement over the existing FTAs. This means harmonising the trade and regulatory rules between ASEAN members and their FTA partners and minimising trade-diverting effects.

It is important for ASEAN to make convincing progress in RCEP negotiations, set conveniently to conclude and coincide with the commencement of the AEC in 2015. ASEAN has now arrived at a critical juncture where the AEC's credibility will require ASEAN to choose the path of bold action to improve the rules governing ASEAN FTAs. This is deeply linked with RCEP's goals, and while it is not necessary for ASEAN to first complete all of its AEC Blueprint measures to conclude the RCEP, 


\section{BANDAR SERI BEGAWAN}

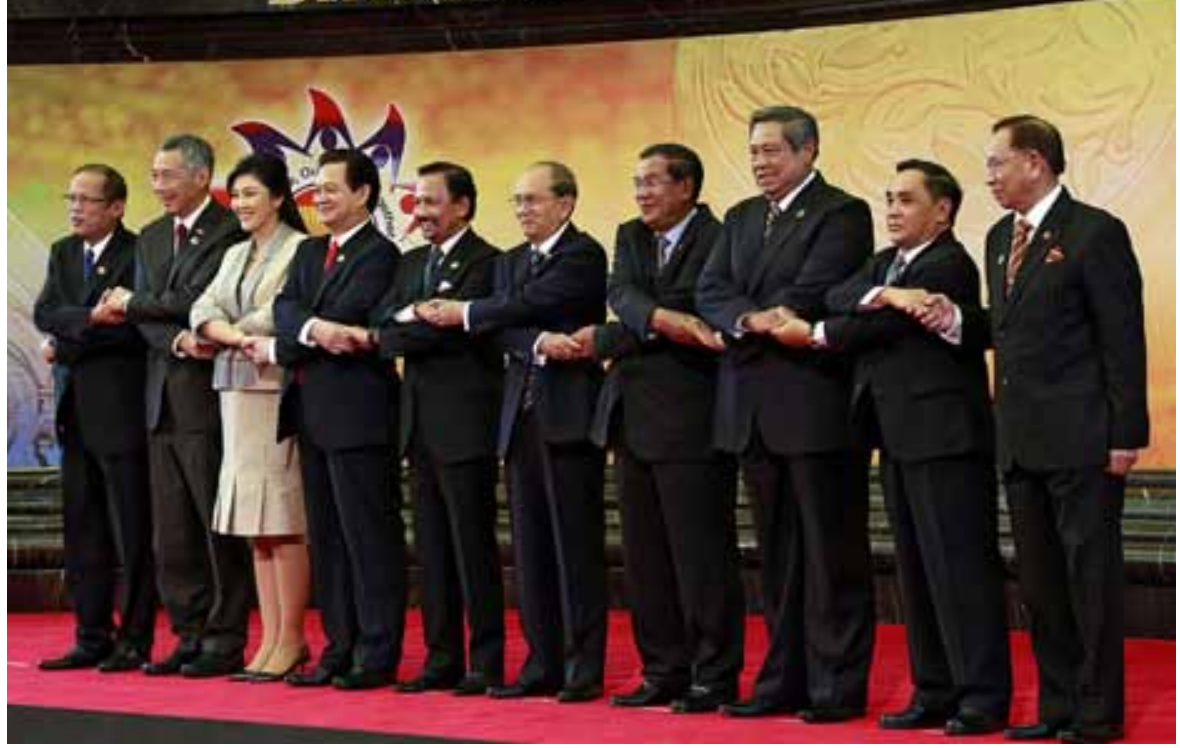

Joining together: ASEAN leaders in Brunei in April 2013. Indonesia set the creation of an ASEAN Economic Community by 2015 as the group's central objective but progress to date has been modest.

meaningful progress, in at least some of the more difficult areas, like services liberalisation, is important. This is critical for ASEAN if it is to reach the required ASEAN common position vis-à-vis the dialogue partners for RCEP negotiations.

Moreover, deeper intra-ASEAN integration is a prerequisite for a broader East Asian integration led by ASEAN. ASEAN functions as a 'hub' with linkages or spokes to countries (the dialogue partners); at the same time, the hub serves as a platform for networks of production involving all countries connected through the hub (or ASEAN).

In short, now is the time for ASEAN to really focus on its economic integration agenda, and Indonesiaas the most influential country in ASEAN-should take a leading role in this.

Given the impending 2015 deadline, Indonesia should focus on issues that are difficult to solve but critical for AEC's realisation. As a number of studies have suggested, non-tariff measures and services liberalisation stand out.

ASEAN has been successful in tariff elimination but not so in reducing barriers stemming from non-tariff measures. Significant non-tariff barriers applied by ASEAN member states can negate the positive impact of tariff elimination. And dealing with non-tariff measures is even more important, given that some of them can be used for short-term protectionist purposes, especially during downturns.

Services liberalisation, meanwhile, is critical-especially for services needed as inputs for production such as logistics, transport and business services. Probably the biggest challenge for ASEAN in services liberalisation (pursuant to the ASEAN Framework Agreement on Services) is how ASEAN member states can arrive at substantially more open commitments to foreign commercial presences in their domestic economies. On this, a more open investment regime is necessary to create incentives for firms to invest across ASEAN countries.

But there are obstacles to Indonesian leadership in ASEAN too. For one, Indonesia faces a number of domestic economic challenges. Issues in infrastructure development, a high dependence on natural resources for generating income, a more rigid labour market, and continuing development gaps between regions within Indonesia are just some of the key concerns. All these are known to have eroded the country's overall competitiveness in the past decade or so, especially in comparison with other ASEAN countries. These challenges also indicate that the country's economic structure is (or will be) changing, and will likely still be doing so for many years to come, continuing the process started in the early 2000s.

The best way forward would be for Indonesia to engage both challengesdomestic economic reform and reform of ASEAN leadership-together. Commitment to achieving AEC and RCEP by 2015 will have the effect of instilling discipline at home for implementing the necessary domestic reforms. Even if the 2015 deadlines are not met, a decisive resolution to Indonesia's domestic issues will benefit the country's competitiveness, regardless of whether the region is fully integrated. At the same time, improvements to competitiveness will create momentum for increasingly bringing Indonesia into a more integrated region. ERFQ

Dionisius Narjoko is a researcher at the Economic Research Institute for ASEAN and East Asia, Jakarta. 


\section{Time to regain confidence}

\section{SJAMSU RAHARDJA}

I NTEGRATING with the global

market place was once Indonesia's strategic offensive choice to accelerate economic reform and development. Indonesia has benefited significantly from opening up to trade and investment. It responded without hesitation to plummeting revenues from oil exports in the early 1980 s with sweeping reforms to reduce tariffs, non-tariff barriers, red tape in customs clearance and procedures for obtaining business permits. These reforms spurred the expansion of light-manufacturing industries and helped the economy reach a steady rate of per capita real income growth of 5 per cent per annum until the Asian Financial Crisis in 1997.

Alongside domestic reforms, Indonesia was a champion of economic integration and openness on the international stage. In the 1990s, Indonesia led APEC's Bogor Goals declaration and its leadership also helped create the ASEAN Free Trade Agreement in 1995. As a member of the G20 process, host for the 2011 ASEAN Summit and recent host of the 2013 APEC Summit, Indonesia has supported old and introduced new initiatives for economic cooperation, especially in regard to connectivity and infrastructure. Indonesia is also one of the main advocates of the Regional Comprehensive Economic Partnership agreement, one of the most ambitious trade liberalisation vehicles currently being negotiated in Asia.

Yet in Indonesia there seems to be growing caution towards greater economic integration. In recent years regulatory and incentives regimes have become more domestically oriented. Although Indonesia's average import tariff is relatively low at around 7 per cent, many imports are subject to new administrative requirements like pre-customs inspections and various permits. Indonesia's services sector has not become more open to foreign direct investment (FDI) since 2003, with several areas remaining restricted to foreign participation. Strict cabotage rules limiting the ability of foreign providers to service Indonesian domestic sea lanes, combined with restrictions on FDI in ports, warehousing, and freight forwarding, mean Indonesia's logistics sector is less exposed to competition than its main regional competitors. And with the ASEAN Economic Community to be fully implemented in 2015, there is now pressure on the government to protect domestic businesses and impose new restrictive measures on trade and FDI.

The sentiments behind these policies are understandable. Indonesia wants an equitable industrialisation process led by Indonesian entrepreneurs. The Indonesian economy is also sensitive to its current account deficit, which gives the impression that its industrial structure is too thin and dependent on imported goods and services. Trade balance is vulnerable to commodity price shocks as more than half of its export value comes from commodities and natural resources, whereas imports are mainly of capital goods and intermediate products. Indonesia needs to continue facilitating industrialisation to move out employment that is currently concentrated in low productivity activities. Some argue that Indonesia should address these issues with less exposure to international markets.

But these concerns are best addressed by pursuing structural reform and taking advantage of further integration with the global economy. Indonesia needs to generate business opportunities to absorb at least two million new workers annually and position the economy to escape the middle-income trap. This requires the economy to exceed the current growth trend of 6 per cent per year, which will be difficult given the prevailing employment growth rate and total factor productivity, and may require doubling investment growth. Given that Indonesia's gap between savings and investment is already substantial and widening, the additional investment will have to come from an increase in annual FDI inflow from its relatively low current value of 2 per cent of GDP.

$\mathbf{R}$ ATHER than pursuing import substitution to slowly develop a complete manufacturing base at home, Indonesia should participate more extensively in regional and global manufacturing chains. This would allow Indonesia to accelerate industrialisation by taking advantage of natural resource wealth, having FDI pay for capital in the form of factories off-shored to Indonesia and leaving the nation free to focus on investing its own resources in human capital and programs to facilitate local industries climbing up the value chain where the value added is greater. 


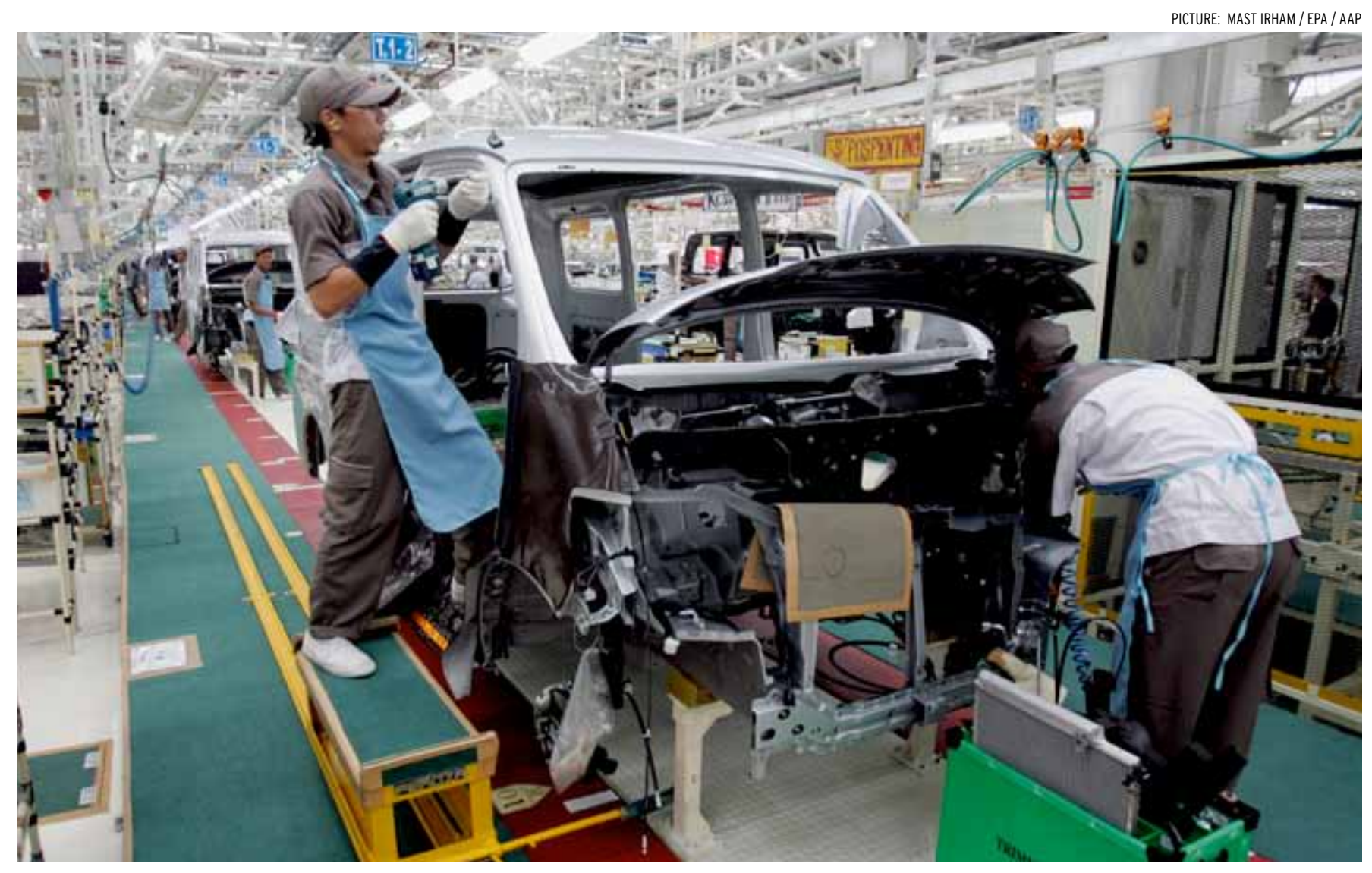

The Astra Daihatsu assembly line in Jakarta: Indonesia 'should participate more extensively in regional and global manufacturing chains'.

More openness could also substantially enhance productivity growth. A 2007 study by Mary Amiti and Jozef Konings found that a 10 percentage point fall in import tariffs on intermediate goods led to an average 11 per cent improvement in productivity for Indonesian firms that used those imports as inputs, thanks largely to lower costs. A separate 2009 study by Jens Matthias Arnold and Beata Javorcik suggested that Indonesian manufacturing firms that received capital and technology from FDI experienced, on average, a 13 per cent productivity increase in just three years. Exposing Indonesia's retail, domestic air transport and telecommunication sectors to greater international competition has also been shown to lead to significant output growth with productive spillover effects on the manufacturing sector.

Some domestic companies may indeed be unable to withstand global competition or benefit from further integration. However, it would be preferable for industrial policy not to protect the inefficient practices of such businesses but to help them address their core constraints and improve competitiveness.

A KEY issue in this regard is Indonesia's relatively low public spending on infrastructure and the high cost of doing business. Indonesia must do more to reduce the cost of domestic freight, improve access to energy sources and reduce bureaucracy and regulatory uncertainties so that businesses can adjust rapidly to new opportunities.
More competition in backbone and bottlenecked services such as domestic sea freight, broadband communication and energy distribution would help Indonesian businesses be more cost competitive. There is also room for intervention to improve workers' skills and the capacity of local businesses to innovate.

Indonesia must regain its confidence in economic openness and international integration. Exposure to international economic forces can be difficult to manage at times but is critical for Indonesia to escape the middle-income trap. EAFQ

Sjamsu Rahardja is Senior Economist at the World Bank office in Indonesia. The views expressed are personal and do not necessarily reflect the views of the bank and its Board of Directors. 


\section{What's wrong with the TPP}

\section{YOSE RIZAL DAMURI}

W HEN Indonesian officials are asked about the Trans-Pacific Partnership (TPP) and Indonesia's involvement in the proposed trade agreement, they normally answer that the country is paying attention to the process and the possible results of the negotiation but has no interest in joining the agreement at this time. Doubt over Indonesia's capacity to carry out proposed commitments in the trade deal as well as uncertainty regarding the potential for any significant benefits to the economy are cited as the main reasons for this position.

Indonesia is not very active in forming trade deals with its partners when compared with other countries in the region. While Thailand, for example, has signed bilateral trade agreements with eight partners and is working to conclude nine more in the near future, Indonesia only has two bilateral agreements, with only one implemented. Many proposed bilateral talks with trading partners are stalled, with some, such as the proposed agreements with the European Union, showing little progress for several years. Most of Indonesia's trade agreements are regionally negotiated as part of ASEAN initiatives, such as the Regional Comprehensive Economic Partnership (RCEP), the recently launched trade agreement between ASEAN and its six main trade partners in East Asia.

In this context, it can be seen that Indonesia's ambivalent position towards the TPP comes from the recent general attitude towards openness and integration. Historically, Indonesia is not generally in favour of preferential trade liberalisation, preferring unilateral or multilateral initiatives instead. Through unilateral efforts since the 1980s, Indonesia has maintained a relatively open trade regime. But the country's stance towards liberalisation has varied widely depending on the economic situation.

Currently, negative sentiments about liberalisation and openness seem to be prevalent. Various measures to restrict imports, mostly in agriculture and food products but also more subtle regulations affecting manufacturing products were recently introduced. An obsessive drive to increase value-added and a determination to promote industrialisation have lead to the reintroduction of interventionist policies, including restrictions on investment and the export of unprocessed commodities.

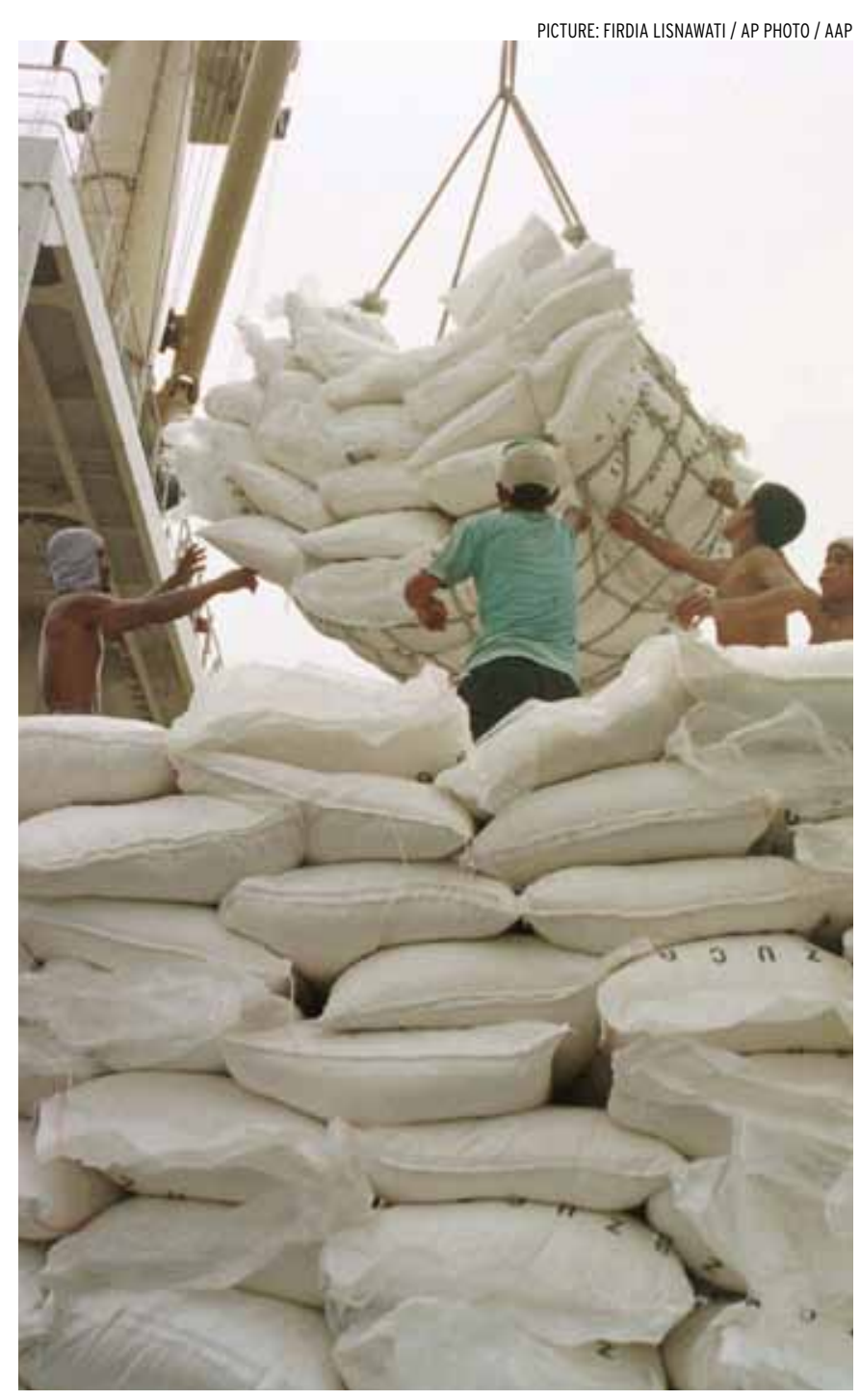

Mexican sugar being unloaded at Tanjung Priok. Measures to restrict imports of food and agricultural products have recently been introduced.

There is a common perception among Indonesian policymakers and government officials that what Indonesia needs at the moment is to improve competitiveness, not to open the economy or expand market access. According to this line of argument, Indonesia should deal with its challenges and problems, such as inadequate infrastructure and high costs, before trying to maintain a more open trade regime and establish trade agreements. Otherwise, Indonesia will be unable to compete internationally and simply be an attractive market for its trading partners. This 
claim is reinforced by the perception that Indonesia's domestic market is big enough to support domestic producers provided sufficient protections are granted and facilities made available for their expansion.

The existing trade agreements are also considered to be unsuccessful in delivering their promises. The agreement between ASEAN and China is blamed for increasing Indonesia's imports while only serving China's hunger for raw materials and energy. The agreement with Japan has not increased market access as Indonesian products cannot meet the standard requirements of Japanese industries and consumers.

Given this attitude, it is not surprising that Indonesia shows little interest in trade deals, including the TPP. As a comprehensive and advanced trade agreement, the TPP covers many economic issues that are not in Indonesia's interests. Joining the trade pact is expected to be costly to the economy and would likely reduce competitiveness even further. Moreover, with only Vietnamgenerally considered Indonesia's main competitor-currently in the TPP, the threat of potential export losses from staying out of the agreement seems limited. Potential trade diversion effects would be serious if China, Thailand or the Philippines were joining the trade deal, but such is not the case with the current TPP members, which are mostly high and high-middle income countries.

Looking beyond the TPP however, Indonesia should change its attitude that the country is not ready for a more open economy. Improving competitiveness and economic integration are not mutually exclusive; in fact they reinforce each other. For one, a more open economy, especially from reciprocal trade agreements, would expand the market base and opportunities for local producers. While Indonesia has a big potential market of 240 million people, its total consumer purchasing power is not as big as that of most developed markets. An outward looking trade regime would facilitate Indonesia participating more actively in the global and regional production network. Its involvement is currently very low.

Trade agreements would also increase Indonesia's attractiveness as an investment destination. Low border barriers reduce the cost of production by allowing investors to source capital and intermediate goods more efficiently. Reciprocal greater market access also means that those same investors can sell their products in the partners' markets more easily, not merely for domestic consumption. With foreign direct investment (FDI) of less than 3 per cent of its GDP, despite recent increases, Indonesia needs to draw more investment from abroad.

Finally, trade agreements can increase transparency and improve the predictability of Indonesia's economic policy direction, a necessary condition for attracting more FDI. With various measures aimed at behind-the-border problems, highlevel trade agreements such as the TPP provide support for the regulatory reforms Indonesia needs for further economic development. Engagement

\section{Competition puts pressure}

on producers to work efficiently, to be more innovative with negotiations for such high-level agreements would allow Indonesia to learn from best practice how to effectively regulate its economic environment.

Improving competitiveness usually goes hand in hand with competition.

Competition puts pressure on producers to work efficiently, to be more innovative and eliminates rent-seeking activities. The most effective way to introduce competition is by opening up the economy to imported goods and services. For example, Indonesia's service providers, such as those in the logistics and transportation sector, would produce higher quality and more efficient services if they had to face competition from overseas providers. This would have positive downstream effects by ensuring better support for economic activities.

Trade agreements should not be viewed with a mercantilist sentiment. This leads to the conclusion that they are not successful unless they increase exports. The gains from liberalisation take many forms, ranging from increased foreign investment to opportunities for reform and improved competitiveness, not to mention benefits to consumer welfare. Indonesia may not be interested in joining the TPP in the near future, but the decision should not come from anxiety towards more open policies and trade agreements. The country should take more action in pursuing RCEP and be committed to developing that trade agreement into a high-quality one. This would maintain ASEAN centrality, and help take back the leadership role in regional integration. EAFQ

Yose Rizal Damuri is Head of Economics, Centre for Strategic and International Studies, Jakarta. 


\section{INSTILLING QUALITY}

\section{Public services: the legacy of decentralisation}

\section{BLANE D. LEWIS}

$\mathbf{T}$ HE devolution of public service delivery and financing to local governments in Indonesia was legislated in 1999 and implementation began in earnest in 2001 . The rollout of decentralisation is often characterised as a 'big bang' because of the speed with which it occurred and the striking extent of reforms. It is not an exaggeration to say that Indonesia went from being one of the most centralised countries in the world to one of the most decentralised in a period of just less than two years.

Despite initial widespread support for decentralising government service delivery and financing responsibilities, most observers in Indonesia would appear to be somewhat disappointed with the results. The prevailing view is that local public service delivery has improved little since decentralisation began-despite a very substantial transfer of funds to local governments to discharge their new-found responsibilities.

While some of that disappointment must be a function of overly optimistic expectations about what could actually be achieved in a relatively short period of time, the objective evidence does indeed support a rather less-thanenthusiastic valuation of the impact of decentralisation thus far. School enrollments have increased at all levels of education but Indonesian children's performance on international learning assessments, for example, have remained especially weak in mathematics and even deteriorated in science. In health, immunisation rates have risen quite substantially across many areas of the country but progress in reducing maternal mortality and child malnutrition has stagnated. Perhaps most problematic is the lack of improvement in infrastructure services. While the extent of local roads has increased the overall quality has deteriorated. The percentage of households with access to safe water has actually dropped from 50 to 48 per cent since 2001. More broadly, Indonesia tends to perform poorly in most aspects of local service delivery compared with countries in the region at similar income levels.

What explains the uneven and largely inadequate performance in local service delivery under decentralisation? Most explanations focus on three reasons: insufficient funding of local governments, lack of capacity among local government officials, and poorly designed

\section{EASTASIAFORUM} IN OUR NEXT ISSUE ...

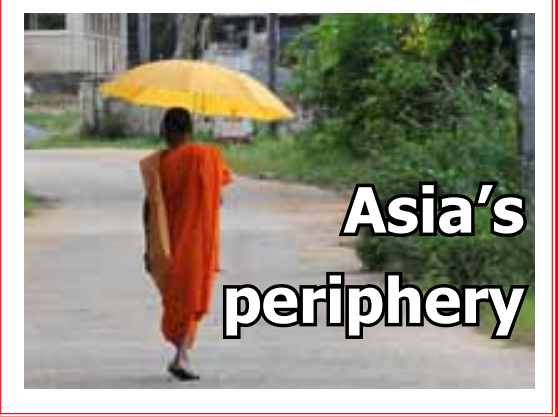

intergovernmental fiscal relations.

The argument that regions generally lack sufficient funds to deliver improved public services seems implausible. Transfers to subnational governments now make up approximately one-half of the national budget (not including subsidies and interest payments) or about 6 per cent of GDP, over 80 per cent of which accrues to subnationals at the lowest level. By contrast, recent analysis shows that transfers to thirdtier subnational governments make up only 0.4 per cent of GDP in India and 3 per cent of GDP in the Philippines. A more credible proposition is that local governments in Indonesia spend their funds in an inefficient and ineffective manner. Recent analysis shows that administrative spending by districts in Indonesia, which amounts to more than one-quarter of total budgetary expenditure, far exceeds international best practice, which posits reasonable administrative spending of less than 5 per cent of budgets. More broadly, the empirical evidence indicates that general levels of spending appear to have little or no effect on a wide range of service outcomes.

Of course, Indonesia is still a developing nation, so the capacity of local governments to deliver services tends not to be as high as it is in more advanced economies. Deficiencies in local government planning and financial management merit some mention in this regard. At the same time, experience shows that there is a great deal of variation in capacity 
across local governments in Indonesia, with the best among them being quite well run. The important question about potential capacity shortfalls, however, is to what extent they occur and where. A defensible view is that most places are not overly constrained by a lack of capacity. In other words, the vast majority of subnational governments could deliver betterquality services now with the capacity they already have.

A number of potential difficulties with current intergovernmental fiscal arrangements have been raised over the years. Perhaps the most frequently voiced concerns of late relate to the 'one size fits all' nature of the intergovernmental system and the disincentives for improved performance embodied in intergovernmental transfers. The uniform treatment of heterogeneous local units in policy design and implementation is clearly a problem for the proper resourcing of local governments. The extent to which this approach affects the general quality of local service delivery is unclear, however, since it appears that the level of funding has little to do with service outcomes in the first instance. Recent research casts significant doubt on the assertion that perverse incentives in intergovernmental transfers have major deleterious local fiscal effects.

An alternative explanation for poor service delivery outcomes would focus on the lack of accountability of local governments towards their constituents. It is well known from international experience that weak accountability and poor local public services go hand in hand. Accountability in this context actually comprises two separate dimensions: an appeal from citizens for improvements to service quality, and a response by local governments to meet
... perhaps the most important initiative that could be undertaken to reform decentralisation would be to convince Indonesia's citizens that they deserve better

constituents' demands. Appeals from citizens implicitly presuppose the existence of some reasonable measure of dissatisfaction with the status quo.

In Indonesia it turns out that citizens actually seem quite satisfied with the quality of local public service delivery. The World Bank's recent Governance and Decentralization Survey, a fairly large project, found that 78, 90 and 85 per cent of respondents were at least somewhat satisfied with the quality of local administrative, health, and education services, respectively. Less than 30 per cent of the randomly selected households in the study indicated that they wanted better administrative and social services and were willing to pay for them. In fact, only 7 per cent of households had ever formally complained about the quality of local government services. Of those that had not complained, more than 90 per cent said it was because they had no complaints about service quality.

So it would seem that the lack of downward accountability at the local level in Indonesia may in large measure be a function of insufficient citizen demand for higher service quality. This, in turn, provides a clear and robust explanation for the lack of observed improvements in local public service quality under decentralisation. That is, if citizens are already reasonably satisfied with the quality of service delivery, there would seem to be little reason for local governments to strive to improve it.

In this context, two possible conclusions present themselves. The first is that the quality of local services in Indonesia is already good enough and that there is no real need for improvement. The objective evidence seems to indicate that this is not true, but on the other hand it appears as if Indonesian citizens themselves are reasonably satisfied with the amount and quality of local service delivery. If this is the case, then Indonesians already have the decentralised system of government that they want and deserve.

Second and the view expressed here is that the status quo is not acceptable. In that case it would seem that perhaps the most important initiative that could be undertaken to reform decentralisation would be to convince Indonesia's citizens that they deserve better and to encourage them to vigorously express their demands to their local leaders. Only then will local governments be forced to make good on the potential benefits of decentralisation. This is clearly an objective that can only be realised in the long term, but this is indeed how we should see decentralisation-as a long-term process. It is still early days and reformers both inside and outside government must remain vigilant in demanding necessary changes. EAFQ

Blane D. Lewis is an independent consultant based in Jakarta. He has served as an adviser to the Indonesian government under the auspices of the World Bank, among others. 


\section{THE INFRASTRUCTURE DEFICIT}

\section{Mobilising private investors}

\section{HERFAN BRILIANTO}

$\mathbf{T}$

HE SIZE of the infrastructure

challenge across Asia is daunting.

A 2009 Asian Development Bank

Institute study showed that between

2010 and 2020 Asia needs to invest

about US $\$ 8$ trillion-or US $\$ 750$

billion per year-just to keep up with

expected infrastructure needs. In

the four years since that study was

published, economies have struggled

to attract investments large enough

to make any inroads into growing

infrastructure deficits.

Governments clearly need to spend more on infrastructure. Indonesia is no exception. However, the task is too big for governments to tackle alone. There is scope for the private sector to play a key role in building and operating economic infrastructure that can generate an acceptable rate of return for investors and, at the same time, make infrastructure markets work better. But this simply will not happen unless governments take serious steps to improve the investment climate in a way that attracts greater private-sector participation. This includes reforms and investments in institutions that are capable of developing a pipeline of genuinely bankable projects.

Governments often struggle with balancing short- and long-term spending priorities. Often there tends to be a bias towards short-term spending by elected governments to the detriment of much-needed infrastructure investment, which is generally long-term in nature. Furthermore, public-financed infrastructure sometimes lacks certain features that are needed to maximise efficiency and quality in infrastructure service delivery. For example, since tenders for publicfinanced infrastructure are often awarded to the lowest bidder, there can be a risk that the process will not generate appropriate incentives for bidders to internalise lifecycle cost considerations, an important factor in ensuring long-term service quality.

While private investors are increasingly aware that infrastructure is a promising new asset class, there are considerable impediments to overcome before investors will be willing to increase their involvement. The lack of a suitable investment climate in general is usually quoted as a classic problem in many developing economies.

To gain access to emerging markets, foreign investors may sometimes be willing to accept a lower rate of return or a higher level of uncertainty in some sectors. But it is difficult to do this in infrastructure where investments are usually large and can take many

\section{There is scope for}

\section{enhanced international}

cooperation to help

mobilise resources and

knowledge ... to prepare

and deliver successful

projects years to become profitable-even in highly developed markets. A particular problem is an absence of well-prepared projects that can be viewed by the private sector as safe investments. Bidding arrangements are often opaque and delays within governments with poor institutional linkages mean that investments can end up taking many years to achieve financial closure.

Another problem relates to a lack of suitable investment vehicles for different types of investors. For instance, although there are ample opportunities to lure longterm institutional investors such as pension funds to sink capital into infrastructure, developingeconomy financial markets often lack appropriate instruments to meet investor requirements for aspects such as scale, ratings and liquidity infrastructure. A 2011 OECD survey showed that there were 28 large pension funds in OECD countries holding total assets of more than US $\$ 1$ trillion, of which only about 1 per cent was directed to infrastructure investment.

Looking ahead, the Indonesian government, like others, will need to focus energy on building capacity for both long-term infrastructure planning and delivering high-quality investment opportunities for the private sector. That means public officials need to have adequate skills to manage all aspects of projects, from conception through to implementation. In doing this, economies should not work alone. There is scope for enhanced international cooperation to help 


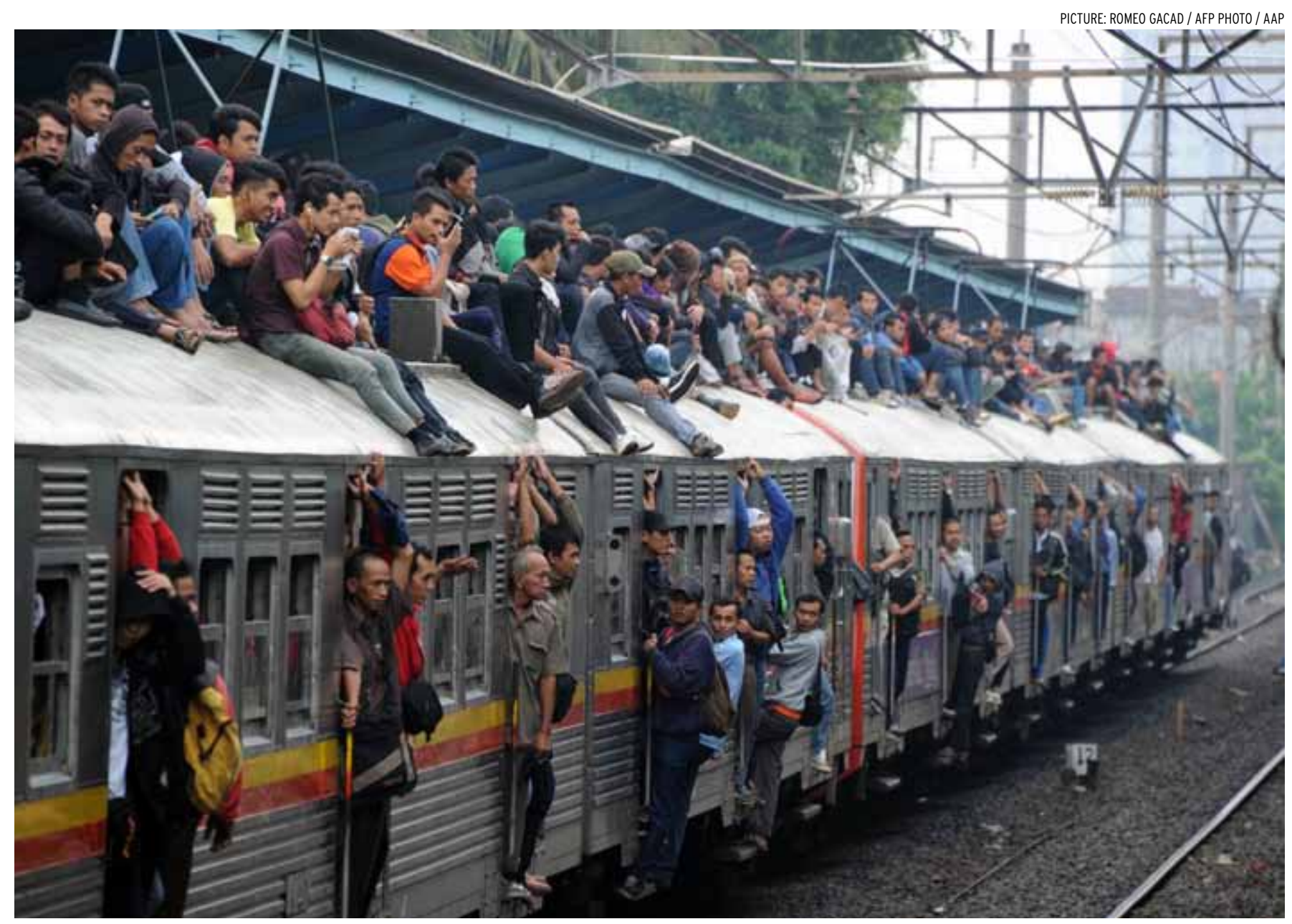

A crowded train pulls into Jakarta's Tebet station. The private sector could play an important role in building and operating critical infrastructure.

mobilise resources and knowledge to help developing economies to create appropriate capacity to prepare and deliver successful projects. This kind of capacity needs to be developed across government systems rather than focusing on specific project deals. It is also difficult to underestimate the role that supportive regulatory frameworks can play in building investor confidence. These kinds of reforms will not happen overnight, but they are essential given the long-term nature of the infrastructure challenges confronting Asia.

With these challenges in mind, APEC finance ministers agreed, under Indonesia's leadership, to create a public-private partnership
(PPP) Experts Advisory Panel to help APEC economies to develop capacity to create pipelines of bankable infrastructure projects. The panel's first task will be to support (as a pilot project) the Indonesian Ministry of Finance's ongoing efforts to operationalise its own PPP Centre. PPPs can open up new opportunities to scale up infrastructure development in economies and leverage private sector resources to kick-start expensive infrastructure projects that are difficult for governments to fund by themselves. They can also help to encourage governments to take a longer term view or life cycle approach to funding expensive and long lasting assets in the public interest.
The key role in the short to medium term of this addition to the regional architecture is to provide mentoring and advice for new PPP centres-such as those in Indonesia - as a way to build up a capability in PPP centres in the Asia Pacific. In the longer term, the Panel is expected to help mobilise and leverage knowledge and best practices in the region to support good infrastructure practices in emerging markets by creating an opportunity for regional PPP centres to network. EAFO

Herfan Brilianto is the Deputy Director of the Center for Regional and Bilateral Policy at the Fiscal Policy Agency, Ministry of Finance, Indonesia. The views in this article are the author's. 


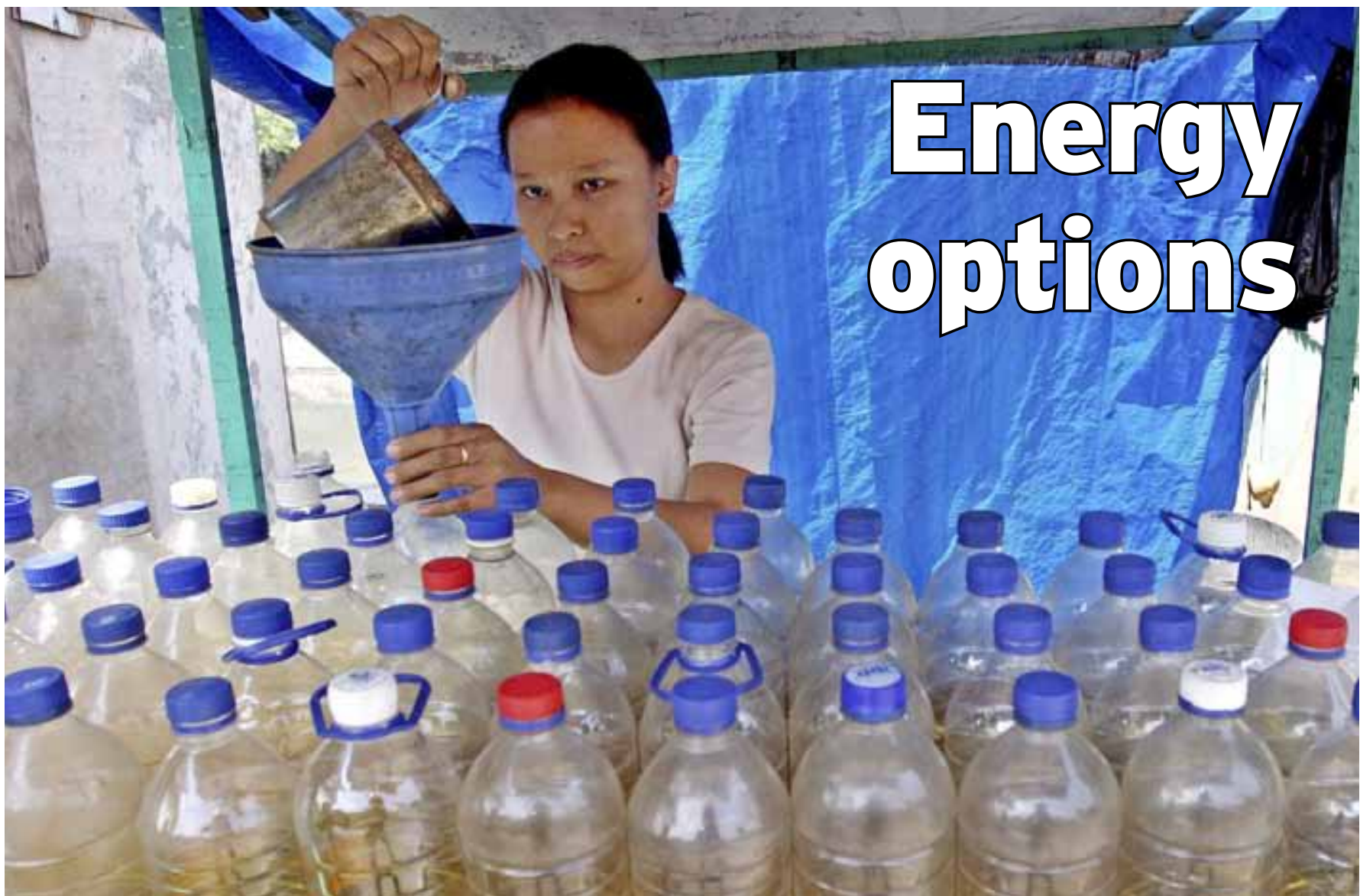

\section{RAYMOND ATJE}

NDONESIA is richly endowed

with energy resources of various kinds: renewable, non-renewable, as well new-energy capacity.

Hypothetically, the government has a reasonably rich list of energy options from which it can choose the most viable resources to exploit. In reality, however, things are not so simple. A number of factors distort and limit the choices available, to the detriment of Indonesia's economic development. This is the energy challenge that Indonesia must address.

Influencing the development of the energy sector is a well-entrenched energy subsidy. Indonesia has subsidised energy consumption since the early days of the republic, and much has been said about how subsidy expenditures may aggravate fiscal imbalances and crowd out public investment on infrastructure as well as on energy. A 2012 IMF Country Report (No 12/278) on Indonesia's economy argued that while the cost of capital is declining, investment in infrastructure (including in energyrelated infrastructure) remains relatively weak. Public investment is hovering at about 3 per cent of the country's GDP, among the lowest in Southeast Asia. Progress with publicprivate partnerships to promote investment in infrastructure has also been slow.

Underpriced energy also distorts resource allocation by encouraging excessive energy consumption. And since the subsidy comes in the form of a price subsidy, most of the benefits are likely to be captured by higher-
A fuel vendor prepares her wares. The subsidy on gasoline is one element that distorts the energy market and encourages excessive consumption.

income households, which tends to exacerbate income inequality.

With a large proportion of the country's energy consumption limited to oil, coal and, increasingly, natural gas, the development in alternative energy forms is lacking. This is also partly due-especially for oil-to the energy subsidy. But history also plays an important role. Indonesia's significant reserves of these three resources meant, like many other countries, it first began to exploit them not only for domestic consumption but more importantly for export, as a source of foreign exchange. Recently, Indonesia has become a net oil importer. Ideally the government 
should be removing fuel subsidies at once to promote efficiency as well as to encourage development of alternative sources of energy. Instead the government has left the subsidy in place, halted oil exports, reduced natural gas exports and redirected some coal exports for domestic use.

It is also important to note that Indonesia is an archipelagic country of around 17,500 islands, some 6000 inhabited. It is inevitable that the market for electricity, for instance, will remain segmented. Even the four main islands, Java, Sumatra, Kalimantan and Sulawesi, where most of the country's population of around 250 million is concentrated, are unlikely to ever be connected by a single power grid. As such, the pattern of population distribution is quite different from the distribution pattern of the country's energy resources. The province of Papua, for example, is sparsely populated but has considerable hydropower potential. Papua is also separated from the rest of the country by a deep sea, making it impossible to send electricity from Papua to other parts of the country.

To address the country's energy challenge, the government has recently set quite an ambitious target: by 2025 the share of oil consumption will drop to 20 per cent from almost 50 per cent in 2011, while during the same period the share of renewable and new energy will increase from 5.7 to 17 per cent of the domestic primary energy consumption. The rest will come from coal (33 per cent) and natural gas (30 per cent). Geothermal energy is included in the renewable energy mix. Currently the country generates around $1.2 \mathrm{GW}$ of electricity from geothermal resources, substantially below its potential which, according to the Ministry of Energy and Mineral Resources, is around $28 \mathrm{GW}$.
In addition, Indonesia's reserves of unconventional gas (coalbed methane) are even larger than its natural gas reserves. The resource is yet to be exploited. The government has also set targets to exploit other renewable energy resources, such as biofuel and biomass.

The ability to meet these targets depends on a number of factors.

First, it depends on the government's willingness to overhaul the country's energy pricing policy. In addition to fuel price subsidiesand despite the acute shortages of electricity faced in some parts of the country-Indonesia's electricity price is among the region's lowest, and does not reflect its relative scarcity. This undoubtedly discourages investors to enter the industry.

Further reform to the energy sector is also needed. The vertically integrated state-owned electricity company PLN (Perusahaan Listrik Negara) continues to dominate the sector. It owns over 75 per cent of the country's generating capacity and most of the distribution systems. Moreover, it retains a monopoly on the transmission system and functions as its system operator. It also has the 'right of first priority', implying that independent power producers can only serve areas that have been

\section{Achieving Indonesia's}

\section{energy targets also}

depends on the

government's ability to

improve the country's

investment climate declined by PLN.

Second, achieving Indonesia's energy targets also depends on the government's ability to improve the country's investment climate. Indonesia needs a huge amount of investment in its energy sector, including energy-related infrastructure like gas pipelines. But various impediments have discouraged investors from entering Indonesia's energy markets (as documented in, among other reports, the World Bank's ease of doing business index, where Indonesia ranks 120 overall).

In the meantime the government is offering investors in the renewable energy sector some forms of fiscal incentives. Such incentives, however, will only work as intended if all the relevant impediments are properly addressed; there is no point in subsidising biofuel, for instance, while subsidies on gasoline remain intact.

It is perhaps more important for the government to instil confidence among potential investors that it is committed to ensuring regulatory certainty, a step that would enable investors to properly assess investment risk. An incentive is rarely necessary when there is regulatory certainty and market mechanisms are able to function properly. Incentive schemes in the form of tax exemptions or subsidies should be viewed as a last resort and only ever provisional in nature. Open-ended incentive mechanisms exemplified by the current fuel price subsidy are not the way to go.

For Indonesia's energy options to reflect the country's resource potential, and facilitate rather than inhibit Indonesia's economic growth, these obstacles must be overcome. EAFO

Dr Raymond Atje is a Senior Fellow at the Centre for Strategic and International Studies (CSIS), Jakarta. 
DANIEL SURYADARMA

A

FTER successfully expanding

their economies from low-

to middle-income levels, many

developing countries now face the

risk of falling into the 'middle-income

trap. The IMF defines this as 'the

phenomenon of hitherto rapidly

growing economies stagnating at

middle-income levels and failing to

graduate into the ranks of high-income countries'.

Indonesia is now stuck in the middle-income mud. The question is: how can it escape to attain highincome status in the foreseeable future?

One potential solution, offered by the World Bank in the case of Malaysia, is to produce highly skilled workers. Basically, an abundance of highly skilled workers allows countries to undergo a structural economic transformation to achieve a more diversified, sophisticated and nonstandard export basket of manufacturing goods, as well as to compete in a globalised services market. The structural transformation will then increase worker productivity and boost economic growth to the rate required to achieve high-income status.

But deep challenges face Indonesia's education sector and limit its ability to produce sufficient numbers of highly skilled workers. Two particularly complex issues are the country's low overall education quality and the low level of tertiary education enrolment.
Indonesia's problem with lowquality education has been widely documented. By way of illustration, a 2013 study by Samer Al-Samarrai and Pedro Cerdan-Infantes states that Indonesia ranked 40th out of 45 countries participating in an international mathematics and science assessment. In that assessment, 72 per cent of Indonesian students performed at the low level, only 3 per cent achieved the high level and none the advanced level. More worryingly, there has been no noticeable improvement in performance on these metrics over the past decade, except in reading.

The same study finds that the problem of low quality is not caused by a lack of public investment. Indonesia is spending one-fifth of its total public budget on the education sector, trying to implement a plethora of reforms, including making the first nine years of education free, requiring teachers to undergo assessment to gain certification, and designing a new core curriculum. These reforms and increased investment have thus far failed to yield much return. Rather the problem appears to be caused by weak governance, in particular how policies are implemented on the ground.

Although the central government still provides significant funding and designs the core curriculum, the dayto-day management of primary and secondary education rests in local government hands. It is responsible for managing teachers (although most teachers are paid by the central government), appointing school principals, and maintaining and building education infrastructure. The huge variation in the capability of local government officials could play a role in stymieing success.

Improved governance of the education sector is needed. This requires an understanding of the governance context in which a particular policy or program succeeds, an analysis of whether such contexts can be replicated in a different locale, and significant capacity-building activities-which may also involve a higher investment in personnel-in local governments that have been identified as suffering from weak governance.

$\mathbf{T}$ HE issue of relatively low tertiary education enrollment will also be challenging to overcome. Currently, the average education attainment of the working-age population extends to around eight years of schooling, with only around a quarter of Indonesians enrolled in tertiary education. There is now evidence of a large and increasing excess demand in the labour market for tertiary-educated workers, which could be hampering the economy from growing to its full potential. Hence increasing tertiary enrolment is a necessary condition to sustaining economic growth and getting away from the middle-income trap.

Unfortunately, the majority of Indonesian households cannot afford to enrol their children in tertiary education. There are at least two policies that could address this issue. 


\section{ENVIRONMENT}

The first is for government to heavily subsidise tertiary education, although there are numerous drawbacks to this option. The opportunity costs of a heavily subsidised tertiary education are very high. Moreover, the subsidy may not be large enough to entice the economically disadvantaged to enrol. Finally, since a tertiary education qualification carries large private returns, there is the argument that students should be required to make a private contribution.

The second policy option may be more viable: increasing participation through a student loan system, something that does not presently exist in Indonesia. Like similar systems elsewhere, the loan would only need to be repaid after the student graduates. A loan system is equitable, because it is available to every individual who wants to enrol in tertiary education. In addition, various studies have shown that a sustainable loan system requires less government funding than a heavy subsidy. Neighbouring countries are currently designing and experimenting with various types of loan systems, and Indonesia would be wise to follow suit.

With the labour market demanding increasing numbers of highly skilled workers, education will be a fundamental issue to ensure that Indonesia frees itself from the middleincome trap, and is equipped to continue along a path of high growth. But without genuine improvements in education governance and an effective tertiary education loan system, it is hard to see how Indonesia will find itself in the high-income domain any time soon. EAFO

Daniel Suryadarma is a Visiting Fellow at the Arndt-Corden Department of Economics, Crawford School of Public Policy, Australian National University.

\section{Climate change: protecting forests for the future}

FITRIAN ARDIANSYAH

LIMATE change poses a grave threat to Indonesia's naturebased economy, including its landuse and forestry sector. But it is also likely to provide good opportunities, especially in the incentives created to support the overall REDD+ program (Reducing Emissions from Deforestation and Forest Degradation plus) in Indonesia.

Based on the projections of the Intergovernmental Panel on Climate Change in its Fourth Assessment Report, a tropical nation like Indonesia is likely to experience an increase in temperature, resulting in adverse effects on vulnerable terrestrial ecosystems, biodiversity and forestdependent people.

This includes an increase in the intensity and frequency of droughts, flooding, forest and land fires and trans-boundary haze, adding to the

... addressing

deforestation and peat

cover loss needs to be at

the centre of Indonesia's development policies and

\section{programs}

already severe existing environmental disasters that are a result of continuous deforestation and forest degradation.

Indonesia, therefore, has a significant stake in ensuring that global negotiations on climate change produce a credible agreed instrument, applicable to all countries, that stabilises and eventually reduces the concentration of greenhouse gas (GHG) emissions in the atmosphere.

It is also crucial that Indonesia opt for a policy or approach that not only safeguards it against the threat that climate change poses to its economic development, but for one that offers it a chance to seize the economic opportunity that climate change presents, such as from REDD+.

Indonesia needs to grow its economy, alleviate poverty and increase the employment rate, all the while protecting the environment and contributing to climate change mitigation. Therefore it is imperative that it decouple its economic growth from GHG emissions.

In the land use and forestry sector, adopting such an approach means that Indonesia needs to find a policy that allows a balancing act. Using the country's forests as an engine of economic growth must be sustainable, which means that addressing deforestation and peat cover loss needs to be at the centre of Indonesia's development policies and programs.

Indonesia has one of the world's largest rainforest areas. In 2009, data from the Indonesian Forestry Ministry 
and the Center for International Forestry Research showed that Indonesia had 132.4 million hectares of forest areas, and that of these only 90.1 million hectares were covered by forest vegetation.

The same data revealed that forest areas covered 71 per cent of the total land area; of this roughly one-third was covered by primary forests, onethird by logged-over areas and onethird by vegetation other than forests.

With regards to peat lands, the Indonesian government's National Working Group on Peatland Management estimated that in 2006 Indonesia had around 20 million hectares of peat lands or 50 per cent of the world's total tropical peat lands, distributed mainly in Sumatra, Kalimantan and Papua.

Forests have long served as a source of economic growth. Commercial exploitation of natural forests began in 1967 and was one of the main drivers of the Indonesian economy from the 1980 s to 1990 s. During these periods, Indonesia secured a substantial global market share in tropical timber products through its exports of logs, sawn timber, plywood and other timber products.

The Forestry Ministry reported in 2006 that the export value of forestry products reached US\$6 billion in 1999 (about 16 per cent of the value of total non-oil and gas exports) and US $\$ 6.6$ billion in 2003, having increased from about US\$1.2 billion in 1985 .

Accelerated development activities in the forestry sector, however, have been perceived as directly linked to forest cover loss. A 2008 study by a team from Utrecht University argued that the loss is mainly due to logging (timber extraction). This practice, for instance, often leads to opening up previously unexploited forests ('primary' or 'virgin' forests), leading to

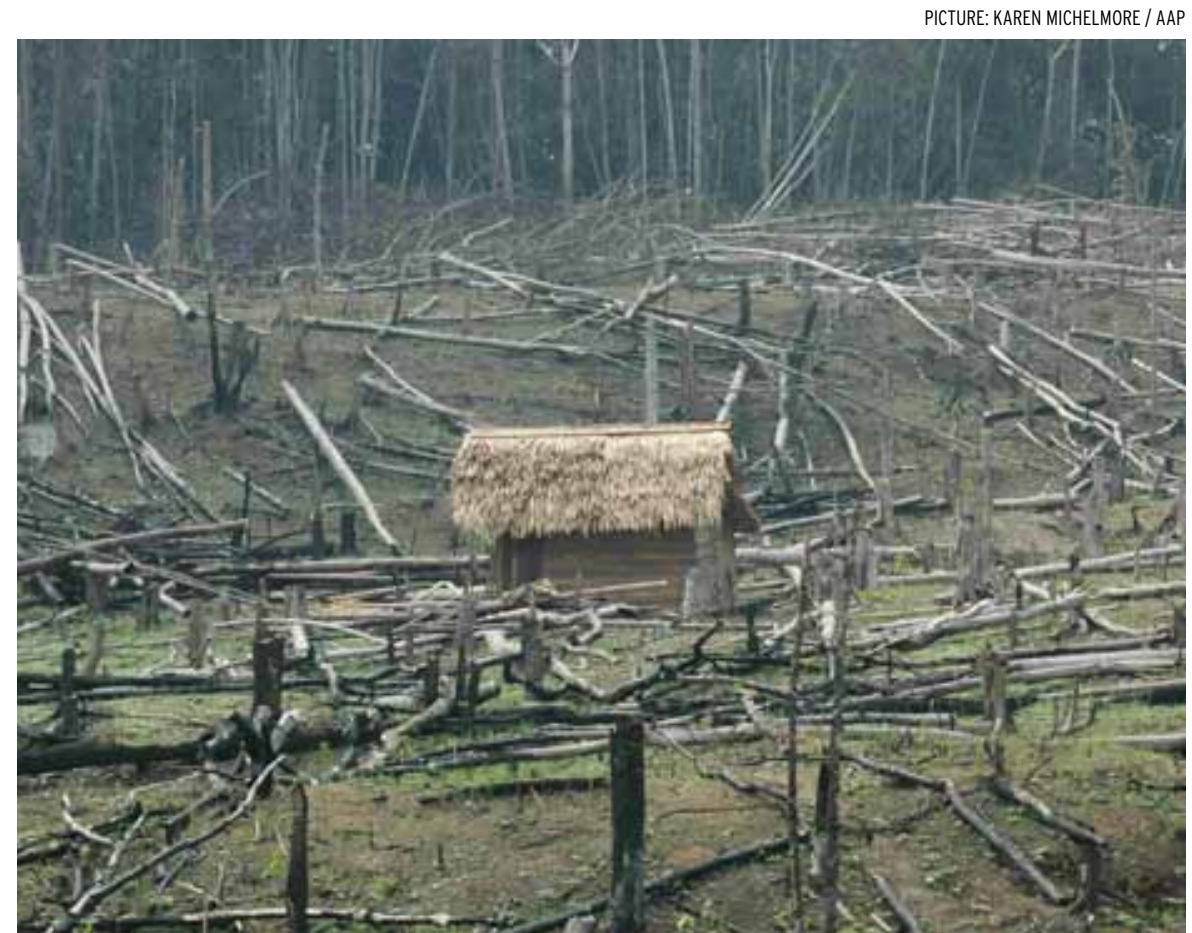

A devastated forest area near Bugit Tiga Puluh National Park, in Jambi, Sumatra. The archipelago's economy could be endangered if governments do not insist on responsible development.

further forest degradation and outright deforestation.

The gradual reduction of forest areas also contributes to the decline in the forestry sector's proportional contribution to the country's GDP. When forested areas are lost, other commercial activities in the landuse sector, especially estate crops development, take over.

As a result, over the past two decades estate crops, mainly palm oil, have emerged as one of the most significant contributors to Indonesia's economy, topped only by oil, gas and mineral products.

In 2009, Indonesia surpassed Malaysia to become the world's biggest palm oil producer, following big increases in production in recent decades. The change is relatively dramatic: in 1967 Indonesia's production of crude palm oil (CPO) was 105,900 tons, increasing to 6.4 million tons in 1999, as reported by the Directorate General of Estate
Crops. By 2010, production had soared to 19.8 million tons.

This growth has been marked by the expansion of plantation areas and has been followed by an equivalent expansion in Indonesia's CPO exports and revenues. These have increased significantly in recent decades, from 3.8 million tons (valued at US $\$ 1$ billion) in 1999 to 17.85 million tons in 2010 (US $\$ 10.03$ billion), according to the same report. It reveals that Indonesia also possesses the largest area of land in palm oil plantations in the world-about 7.8 million hectares in 2010.

Rapid expansion of palm oil plantations has contributed to the conversion of a significant area of forests and peat lands. Several studies argue that palm oil is the greatest immediate threat to biodiversity, forests and peat swamps in Southeast Asia.

Sustaining the management of large remaining forests and peat lands, and 
protecting or conserving these areas, requires strong political will, policy transformation, institutional reforms, innovative economic instruments and behavioural changes.

In a big, democratic and decentralised country such as Indonesia, this means the government needs all the support it can get to ensure that the desired changes take place on the ground. That support is needed particularly from local governments and sectoral ministries as well as local communities and the private sector.

Hence an institution like the new national REDD+ agency, introduced by President Yudhoyono, is confronted by a huge task, particularly in being seen to be inclusive, taking into account the voices of both the winners and losers from REDD+ policies. It must also demonstrate its integrity in carrying out its policies, ensuring the conservation and sustainable management of forests and peat lands. If this does not happen, the development of REDD+ may not yield an effective outcome. This will undermine the country's overall climate change mitigation and adaptation programs, and weaken future efforts to save Indonesia's remaining forests.

With the 2014 general election not far away, issues of climate change mitigation and forest protection should be in the mainstream economic debate. Potential Indonesian leaders and the public should be reminded that this archipelago's economy could be in jeopardy if responsible development is not chosen by the present and future government. EAFC

Fitrian Ardiansyah is a PhD scholar at the Australian National University and the recipient of Australian Leadership Award and Allison Sudradjat Award.

\section{Rehabilitating terrorists: management,
not ostracism}

NOOR HUDA ISMAIL

D RISON regulations in Indonesia allow 'good' inmates to be released early on remission, a policy that can apply to people convicted of terrorism offences. But sadly, since 2002 at least 28 of the around 350 excombatants released have reoffended. This raises some important questions. After an ex-combatant has been released from prison, what causes him to re-offend? And what can society do to prevent this from happening?

The options for released excombatants are stark. Do they return to jihad or do they re-enter society to lead a normal life? In general, people convicted of terrorism offences are released into difficult social and economic conditions. They often lack education and find that their family does not support them. Without help, the there is a high risk that a former terrorist inmate will return to the

\section{Disenfranchised youths}

are always at risk of

being radicalised jihadist community, where he will be protected and cared for.

My approach to this problem has been to engage directly with excombatants through a social enterprise initiative- $\mathrm{a}$ food business chain called Dapoer Bistik in Semarang and Solo, Central Java. Food can provide an excellent platform for nearly everyone to start engaging with each other. In Indonesia, food has been widely used to promote peace in the past. One example is the celebration of Padungku in Poso, where Muslims and Christians eat together to thank God during harvest time.

My first 'client' was Yusuf Adirima, a former Moro Islamic Liberation Front (MILF) fighter from Indonesia who was arrested in Semarang in 2003 for storing explosive materials. We first met that year when, in my former life as a journalist, I interviewed him in the Semarang Police Detention facility.

To engage people like Yusuf you must empower them. If Yusuf felt he had a reasonable control of his destiny, he would be less likely to return to radicalism. Through social and psychological engagement an individual's commitment to and involvement in violence can be reduced to the extent that the risk of returning to violent activity will be low. 
Drop-out students benefit from Dapoer Bistik too. Merely being employed is not everything for former terrorists-they need to feel they are a part of society again. So I encouraged Yusuf to start searching for drop-out students willing to work at the restaurant. This gave him a feeling that he was a useful member in the community because he was helping to solve one of Indonesia's acute social problems: unemployment. Moreover, disenfranchised youths are always at risk of being radicalised. Now every decision Yusuf makes has a direct impact on other people's lives. It's harder for him to go back to clandestine activities and re-engage with his old network. Dapoer Bistik provided him with a new social network, one that gives him selfrespect and dignity. Yusuf slowly became comfortable with his new life and started to invite other excombatants to join his new cause.

But, by themselves, individual programs like Dapoer Bistik can only have limited impact. The state needs to be involved as well. Indonesia can provide training that will help corrections officers to actively engage with the former inmates and support ex-combatants to find new callings in life. And it can get in contact with the families of former inmates, because parental and familial pressure can help steer the young men away from violence. This pressure may be overt or subtle. Parents who merely express sadness, dismay, fear or shame toward their sons can influence the choices they make in the future.

If the government is involved, it will gain more than just reassurance that the people it releases won't return to terrorism. A former terrorist's history and information can help provide important pieces of the mosaic of ongoing investigations-intelligence to

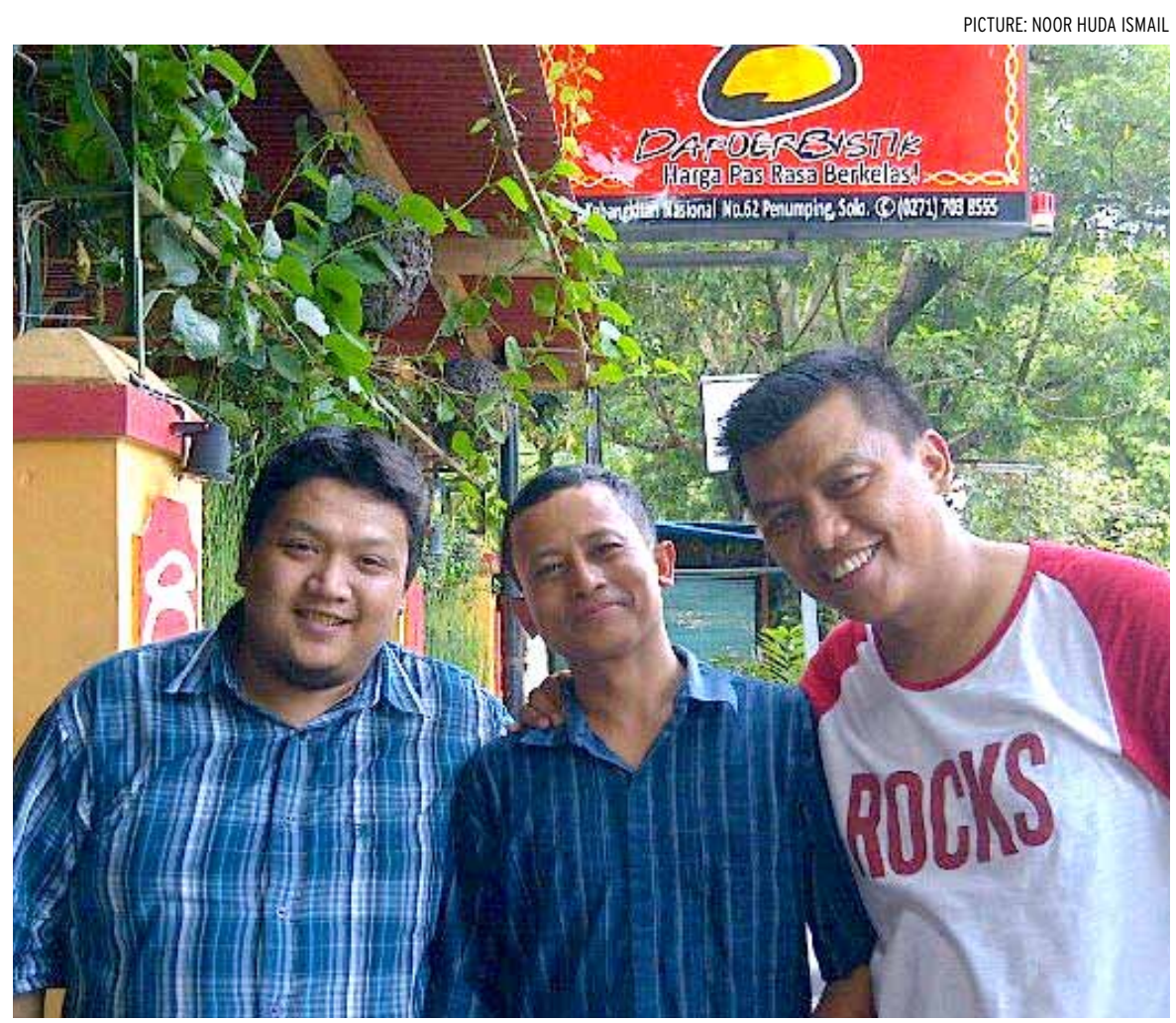

Yusuf Adirima, centre, with the author, right. The Dapoer Bistik program shows that if people feel they have control over their destiny, they are less likely to return to terrorism.

prevent terrorist plots.

Some critics argue that governments should not directly engage former inmates convicted of terrorism offences, especially using the national budget, because the funds may be redirected for terrorism activities. There is the argument that terrorists should be locked away for life. The United States has implemented this policy, and terrorism offenders in American jails have no chance of rehabilitation. But while in Indonesia most arrested terrorism offenders will eventually be released, the existing system has insufficient funds, infrastructure and resources for their rehabilitation. This lack of post-detention care puts such inmates at risk of returning to violence because they are not being properly assessed and are receiving insufficient support to return to mainstream society.

I hope my modest work can be useful as a model that can be leveraged and tailored to fit different cultures and contexts. However, a significant amount of time and financial investment is needed, particularly for those newly convicted of terrorism offences. One person can help perhaps 10 ex-combatants at a time. But what if there was a network of capable volunteers and NGOs? Together, we would be able to reach out to many Yusufs and, through them, help many more former militants re-enter Indonesian society so that they will not return to lives of violence. Such services would also contribute to part of the presumed role of the state. This is one way in which the Indonesian government needs to take a fresh look at its counterterrorism agenda. EAFQ

Noor Huda Ismail is Founder and Executive of the Institute for International Peace Building, Jakarta. 


\section{Capital flows: managing the benefits and risks}

HARTADI A. SARWONO

$\mathbf{T}$ HE resurgence of capital flows to emerging economies took on renewed importance with the growing attractiveness of investment in Asia and elsewhere compared to investment in industrial economies. The success in managing capital flows generates a great deal of benefit in development, but failure can jeopardise both internal and external stability. A surge in capital inflows can also pose a range of policy challenges, including macroeconomic risks through excessive credit expansion, an overheating economy and an overvalued real exchange rate. There is also risk of currency crisis and financial instability if conditions are suddenly reversed.

There is no single recipe for success in reaping the rewards and avoiding the risks from capital flows, and authorities need to use all the available instruments at hand. Bank Indonesia has implemented a range of policies to manage the resurgence of capital inflows since 2009. The authorities' first priorities were sound and sustainable macroeconomic and financial policies to create an environment conducive to encouraging capital flows. Bank Indonesia also pursued prudent monetary policy under its Inflation Targeting Framework, at the same time as the government maintained a sustainable fiscal policy with a budget deficit below 2 per cent of GDP and effective control of government debt.
Strong fundamentals are necessary, though not sufficient to manage a surge in capital flows. That calls for other measures that together help maintain stability. In Indonesia, these measures do not aim to control the volume of portfolio flows. Rather, they are designed to reduce volatility and sustain financial stability by maintaining a flexible exchange rate through selective foreign exchange intervention and by targeted macroprudential measures.

$\mathbf{T}$ HE ROLE of exchange rate flexibility in managing capital flows is critical. Exchange rate flexibility can serve as a shock absorber that eventually helps to lessen the chance of overheating and dampen pressure on other asset prices. But an excessive appreciation of the rupiah during a period of capital inflows also has potential to disrupt the economy more generally. Against this background, Bank Indonesia conducted a sterilised intervention in the foreign exchange (forex) market. This helped to contain excessive exchange rate volatility, while allowing the rupiah to move in line with Indonesia's economic fundamentals. Yet this strategy cannot be used to cushion against large and persistent capital flows. It is just one aspect of the broader policy mix.

Bank Indonesia also undertook a parallel intervention in the government bond market. During a period of capital flow reversal caused by foreign holders selling off government bonds, Bank Indonesia used some of the rupiah absorbed from its intervention in the forex market to purchase these government bonds in the secondary market. Thus far, the intervention has successfully stabilised markets and avoided a further drop in the rupiah and government bond prices.

Bank Indonesia then tightened its money market operations to sterilise the liquidity generated from its intervention in the forex market and to prevent undue impact from short-term capital inflows. As part of this strategy, Bank Indonesia has lengthened the duration of Bank Indonesia certificates (SBIs) and introduced non-tradable monetary instruments to absorb both excess rupiah liquidity (using rupiah term deposits) and excess forex liquidity (using forex term deposits). These instruments are non-transferable, thus reducing the ability for financial assets to be traded by foreign investors. These policies have improved the ability of the central bank to absorb excess liquidity, and have also helped to eliminate carry trade and arbitrage.

In some circumstances a purely macroeconomic policy response is simply not adequate. For this reason Bank Indonesia also introduced its capital flow management scheme and a series of macroprudential measures (MPMs). The two are often described in similar terms, but their primary objectives do not automatically overlap. Indonesia's capital flow management scheme comprises 


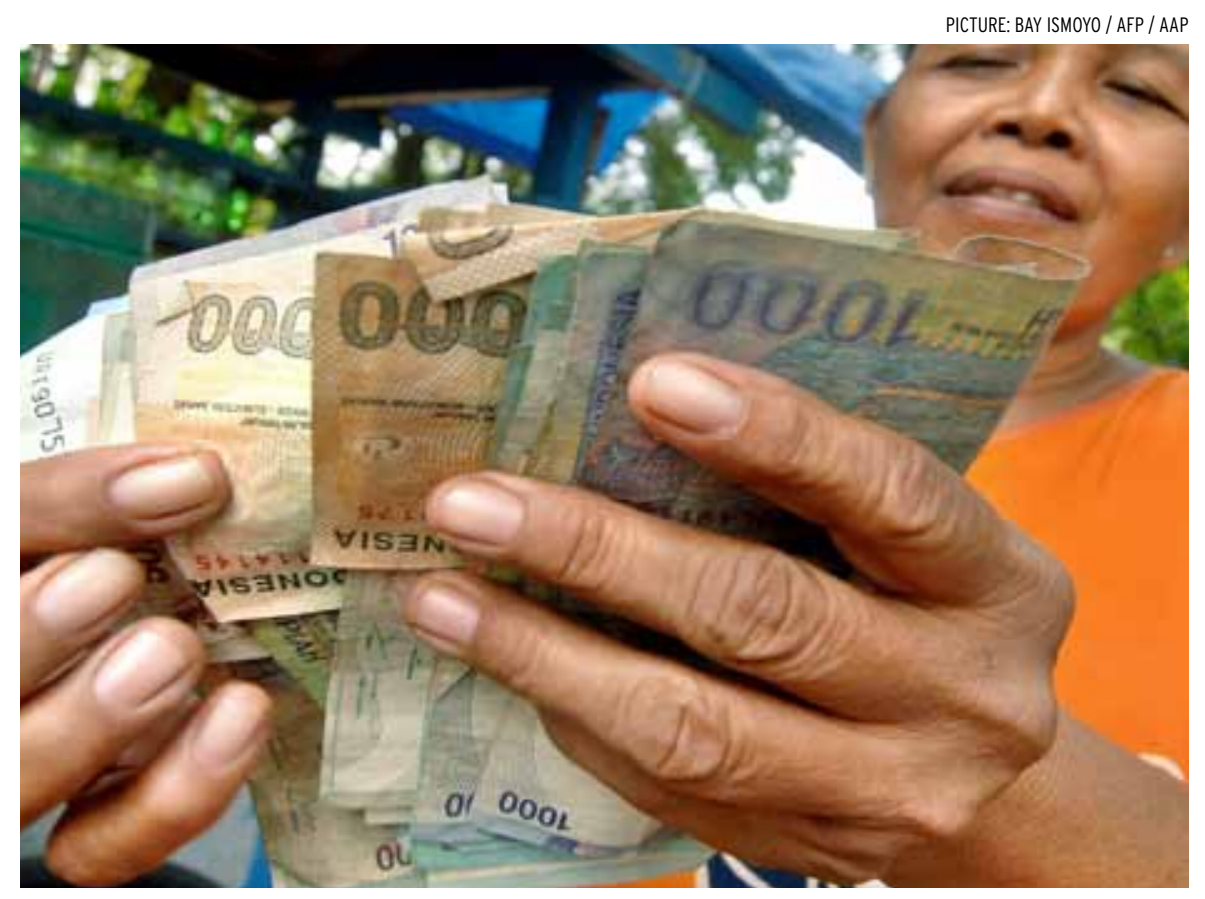

A generous handful of rupiah in a Jakarta stallholder's hands. The Indonesian currency has come under increasing pressure from the global financial market since late 2012, thanks to market uncertainty and the impact of the country's widening current account deficit. Now, after a period of strong capital inflows, Indonesia faces the prospect of those flows being reversed.

administrative measures designed to limit short-term and volatile capital flows by containing the scale, or influencing the composition, of these flows, while MPMs are prudential tools primarily designed to limit systemic financial risks, irrespective of where they originate.

As part of its capital flow management strategy, Bank Indonesia issued a month-long holding period for SBIs. Besides preventing a sudden, large-scale reversal of capital, the policy was also designed to channel capital flows from these certificates into more productive portfolios, such as government bonds and equities. Macro-prudential measures include a policy on reserve requirements to absorb undue liquidity stemming from substantial capital inflows and excess liquidity in the banking system. Bank Indonesia also implemented other measures to manage excessive credit growth in certain sectors by strengthening the loan-to-value ratio. This policy is expected to shift funds into more productive lending and could also strengthen the banking sector.

This policy mix has been beneficial in sustaining capital inflows and lessening risk. The policies are supposed to maintain capital inflows, shift the composition of investment, expand foreign direct investment (FDI) and eventually contain exchange rate volatility. Unfortunately, from the second half of 2012, the rupiah has come under increased pressure from global financial market uncertainty and the impact of the widening current account deficit. The latter was caused by an expansion of imports following strong domestic demand growth, coupled with slackening exports. After a prolonged period of strong capital inflows, Indonesia now faces capital outflow due to more volatile external conditions and higher risk premiums. Exposure to capital flow reversal has increased, depreciation of the exchange rate has accelerated, and losses to foreign exchange reserves have mounted. Capital flow reversals, combined with increasing risks in investment, have led to a decline in stock prices, rising bond yields and a further weakening of the exchange rate.

Against this backdrop, Bank Indonesia decided to bolster its existing monetary and financial policy mix in these new circumstances. The Bank gradually raised its policy rates to strengthen control over inflation and to mitigate the possibility of a downward spiral into depreciation and inflation. This policy is also part of a broader effort to ease the balanceof-payments deficit back down to a sustainable level. Bank Indonesia continues to allow the exchange rate to move flexibly in response to the changing fundamentals but it may need to guard against the risks of disorderly adjustment. Deepening Indonesia's financial market is a medium-term priority, and this will be facilitated by measures to create a deep, sound and liquid financial market and a wider variety of financial instruments. The promotion of corporate bonds, for example, is crucial to taking advantage of capital inflows and channelling them into productive sectors-especially to fund badly needed infrastructure. A deep financial market can also insure economies against unanticipated shocks in the financial market. EAFQ

\section{Dr Hartadi A. Sarwono is a former} deputy governor of Bank Indonesia in charge of monetary policy, and currently serves as president and CEO of the Indonesian Banking Development Institute. 


\section{DJISMAN SIMANDJUNTAK}

N A world economy with a clouded outlook, Indonesia impresses as one of the few bright spots, attracting investors and traders from the eight winds. Indonesia is increasingly a necessary part of any market portfolio for players with global aspirations, owing to a projected share of 3.4 per cent of world population by 2015 , ascent to middle-income status (with GDP (PPP) per capita of almost US\$5000 in 2012), and recent growth of 4-5 per cent per annum.

Numerous other indicators suggest that Indonesia may soon graduate to upper middle-income status. These include favourable demographics in a generally ageing East Asia, an increased per capita stock of human capital (defined as the product of health, education and entrepreneurship), positive experiences with open trade and investment policies, relative success in democratisation and decentralisation, substantial goodwill among friendly countries, and earnings from natural resources.

Yet caution is in order when dealing with prospects for long-term transition. Indonesia has experienced rapid growth more than just once, only to be disappointed when growth episodes ended in deep falls. The journey to upper-middle income status - and from there to the highincome world-is a very long one, strewn with barriers and concealed traps. The experiences of earlier champions like Japan, South Korea and now possibly China suggest that to reach the higher ranks of development an escape velocity-and no small degree of luck-is needed.

One critical constraint on Indonesia's growth potential is geography. The popular belief in the natural richness of Indonesia is, after all, not shared by ecologists, who point out the fragility of life on the equatorial belt. Scattered across thousands of islands, the Indonesian nation is a logistical nightmare, with high-speed maritime connectivity a far costlier connection than land and air routes. It is more expensive to transport North Sumatran oranges to Java, for example, than substitutes from China.

$\mathbf{T}$ HIS scattered geography instills among many Indonesians an insular and ethnocentric mindset. Eighty-five years after the 'Youth Oath of Unity', where youth leaders from different ethnicities declared support for one Indonesian nation, ethnic dialects still thrive in government offices and ethnic natives frequently reestablish political privileges in their respective cities and towns. The phenomenon of fragmentation along cultural lines runs very deep in Indonesia, perennially affecting labour unions, the business community and civil society groups, which regularly splinter over the slightest disputes. In post-Suharto Indonesia, characterised by democracy and decentralisation, this has meant that party politics is fragmented into 'dwarf minorities' where the largest party typically enjoys only 20 per cent or so of the popular vote, making horse-trading a constant feature of policymaking and bold decisions politically unthinkable.
Additionally, the country's resource endowment may yet be remembered as a resource curse too. Using foreign exchange as its unit of account, the resource sector is 'naturally' shielded from devaluation. As a result, the resource sector has attracted the lion's share of Indonesia's limited pool of entrepreneurs and professionals. But while the resource sector grows steadily the rest of the economy has been exposed to 'Dutch disease', with an expensive local currency inhibiting manufacturing development by driving up the cost of local exports and retarding economic transformation. With globalisation and contemporary society's rapid rate of technological change, a strong resource sector is insufficient to pull an economy all the way to developed status.

Of equal concern as a barrier to long-term growth is Indonesia's low stock of human capital. In this regard, Indonesia looks somewhat out of place in East Asia, having spent less on human capital accumulation than its neighbours. While the recent initiatives to raise the health and education budgets to a new level are heartening they are not panaceashuman capital accumulation initiatives take a long while to bear fruit. Raising the ability of an average Indonesian manual worker to that of a South Korean competitor-or increasing Indonesia's Programme for International Student Assessment (PISA) scores on science and mathematics from the current level of 371 to Shanghai's level of 600 -is a decade-long undertaking. Much supplementary effort is then needed to translate human capital increases into 


\section{OUTSIDE OR IN?}

higher productivity.

Finally, persistently bad institutions constitute a serious barrier to Indonesia's long-term growth. These will also be difficult to deal with but less so than the barriers hidden in geography and culture. Of the countless institutions that are relevant to long-term growth, those dealing with positive-sum interactions-such as the bureaucracy, which mediates most business initiatives-are the most crucial. In contrast, under the deeply rooted tendency towards fragmentation the speed of growth risks being severely reduced when fragmentation combines with a weak and corrupt bureaucracy, as can be seen at present.

Political leadership is critical to overcoming the sticky barriers to long-term growth and avoiding the notorious middle-income trap. But when coalitions are required, as in Indonesia, followers are of equal importance to success, as it is they who nurture shared commitments by organising themselves better.

To hold such a coalition together a rallying project is needed. By recognising Indonesia's demographic quasi-constants and recent shifts in East Asia and the world economy more generally, 'focussed-industrialisation' of a few key metropolises with good connectivity to the world's commercial centres and their own peripheries could be a strong way forward.

Sustained success in such a program may allow Indonesia to reach an escape velocity and climb gradually nearer to the technological frontier where the most rewarding gains are contested. EAFO

Djisman Simandjuntak is Professor of Business Economics at Prasetiya Mulya Business School, Jakarta.

Old-world

assumptions will cruel dealings with Australia

HUGH WHITE

A SSUMPTIONS that the global order is still run by the AngloSaxons of the world, and that this empowers the Anglosphere to dictate the terms of its relations with others, require a hard reality check. This assumption was always problematic, but it is clearly false today as wealth and power shifts to Asia.

For Australia, creating a long-term relationship with Indonesia that serves Australia's interests is just part of the broader task of coming to terms with the shift of wealth and power to Australia's Asian neighbours, which is what makes this the 'Asian century'. Following the handling of revelations that Australian spies tapped the phones of Indonesia's president and his inner circle, Canberra's links with Jakarta are in limbo. This is in no small part because of a tacit belief within its current leadership that Australia can dictate the terms of the AustraliaIndonesia relationship to suit domestic political agendas and interests without taking account of Indonesia's agendas and interests.

President Susilo Bambang Yudhoyono has said that full cooperation with Australia won't be restored until a 'code of conduct' between Jakarta and Canberra has been agreed to and implemented.
Little has been said in public about what he has in mind. It is hard to be optimistic that a new agreement of any kind would do much to help the management of this inherently complex relationship. After all, the last attempt to set the terms of the relationship-the Lombok Treaty of 2007-has done nothing to help manage the current problems.

But Australia faces the more immediate question of how long it will take to reach an agreement that will allow its relationship with Indonesia to get back to 'normal'. For Jakarta the whole idea is to punish Canberra for collecting intelligence and for responding so ineptly to Jakarta's concerns once the story leaked. Indonesia will thus seek sweeping undertakings from Australia both about future intelligence activities against Indonesia and perhaps more broadly about the management of the relationship, which will be intended to tie Canberra's hands and in effect acknowledge its past wrongdoings.

Moreover Jakarta may well adopt a 'take it or leave it' negotiating posture. President Yudhoyono probably feels under no pressure to close a deal. One of the key lessons from the whole affair is that ructions in the relationship now worry Jakarta much less than they worry Canberra. Unlike Australian Prime Minister Tony Abbott, President 


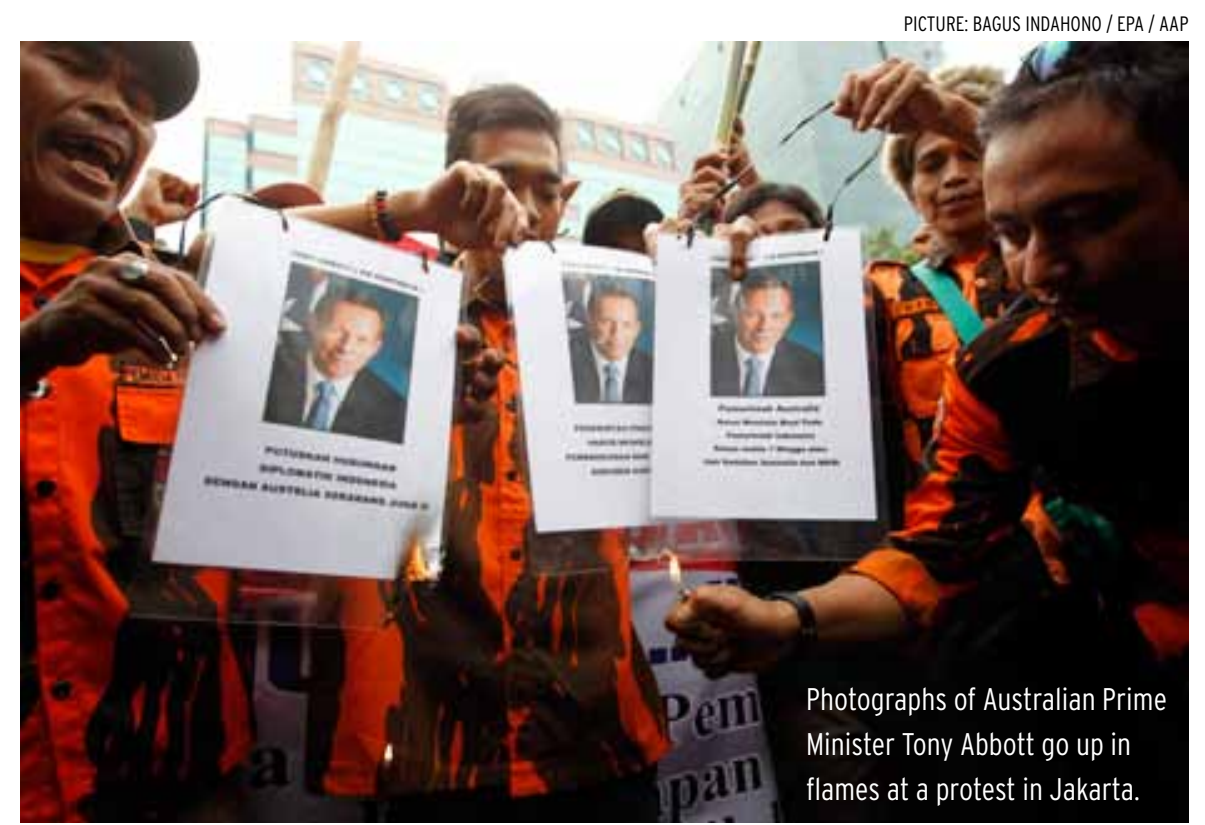

Yudhoyono has never said that this relationship is Indonesia's 'most important overall'.

It will not be surprising if the Australian leader's response to President Yudhoyono's demands prove to be determined primarily by domestic political calculations. One must conclude from the tone of Prime Minister Abbott's initial response (in the Australian Parliament) to Indonesia's initial concerns that it was intended primarily to present an image to Australians of their prime minister as a staunch champion of Australian interests against foreigners, and nothing he has said since suggests a shift in priorities.

What then will shape the Australian government's sense of the balance between domestic political advantage and conciliating Jakarta by agreeing to its code of conduct?

Some will hope that economic factors will weigh heavily in Prime Minister Abbott's calculations. It seems that, in the short term, sensitive export markets like live cattle are at risk as the relationship drifts. Moreover the Australian prime minister has acknowledged that Indonesia's economy will soon enough 'dwarf' Australia's, suggesting that he should recognise major longer-term imperatives to build trade there as quickly as possible. But he also claims to believe that trade can be quarantined from political differences, so that current economic consequences may be too small, and future ones too distant, to affect the calculations much.

$\mathbf{S}$ TOPPING the boats is of course a different matter. It now seems clearer than ever that Prime Minister Abbott's whole 'Jakarta not Geneva' approach to foreign policy was driven primarily by the domestic agenda on people-smuggling, and clearly in Jakarta they expect this to be their best pressure point. How well that works depends on what happens over the next few weeks. Boat arrivals and interceptions have fallen very sharply in the weeks leading up to December, but it is hard to say how much that has been the result of the new government's policies, including the now-suspended deeper cooperation with Indonesia, and how much it results from former Prime Minister
Kevin Rudd's 'PNG solution. The more Rudd's policies have caused the drop, the less effect Indonesia's suspension of cooperation will have in driving the number of boats back up again, and the less pressure the Australian government will be under to sign up to Jakarta's code of conduct. And that means the longer the limbo may last.

Of course eventually, one way or another, the current crisis will pass and the relationship will return to 'normal'. But it will not be without cost or consequences. The inherent fragility in the relationship, so well described by President Yudhoyono himself in 2010 before the Australian Parliament, has been confirmed. Distrust has been deepened. The pattern of regular crises has been repeated. The goodwill of a pro-Australian Indonesian president has been squandered. The opportunity to start afresh, building the kind of relationship Australia needs with Indonesia as its wealth and power overtakes Australia's, has been lost yet again, and time is running out.

Australia has had the same problem with Beijing, too. The Australian government's recent comments about China's East China Sea air defence identification zone presuppose that Australia can say whatever it wishes about issues in which China's interests are engaged without consequences for its relations with Beijing. They are certainly wrong about that, too.

As long as old-world assumptions about an Anglosphere-led world order frame Australia's view of its Asian neighbours-although they are not the only assumptions in the contestCanberra will continue to find itself embroiled in more crises like those of recent weeks. EAFQ

Hugh White is Professor of Strategic Studies at the Australian National University. 

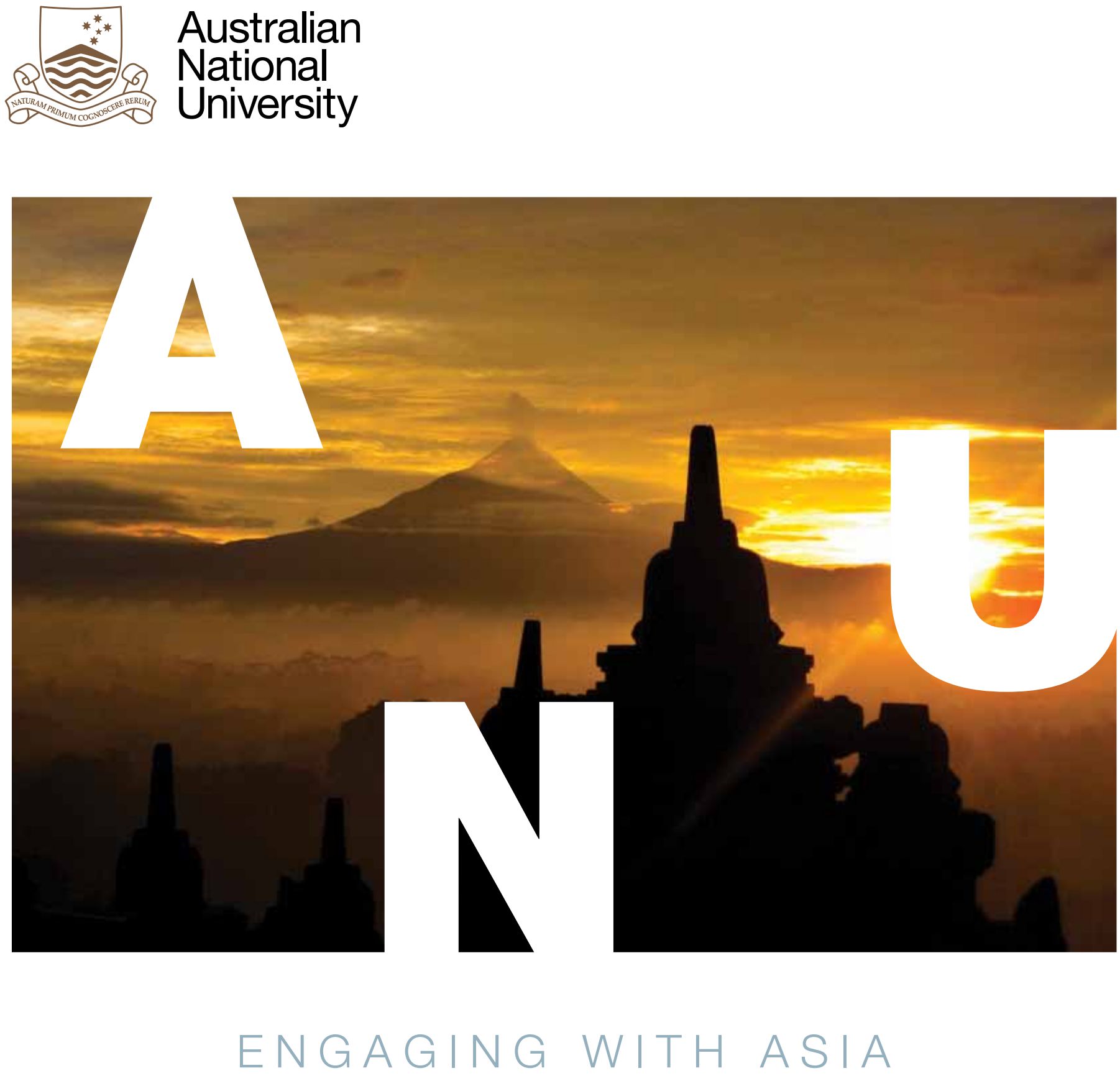

Crawford School is The Australian National University's public policy school, leading and shaping public policy debate in Australia, Asia and the Pacific, through research, professional education and policy engagement. Staff and visitors are active on government committees and play advisory roles across government, business and civil society.

At Crawford School, you will be part of Australia's premier public policy community. Explore your graduate coursework, research and executive education study options in the following fields:

$>$ Public Policy

$>$ Public Administration

$>$ International and Development Economics

$>$ Environmental and Resource Economics

> Environmental Management and Development

$>$ Climate Change

> Applied Anthropology and Participatory Development

Join Australia's leading public policy community today. 